\title{
The Effect of Education Based on the Precede-Proceed Model on the Mental Health of Middle -aged Women referred to Municipal Health Houses of Tehran
}

Maryam Shiani

MSc in health education, Islamic Azad University Science and Research Branch, Tehran, Iran.

Zahra Jalili

* Associate Professor, Department of Health Education and Health Promotion, Islamic Azad University Science and Research Branch, Tehran, Iran. (Corresponding Author).

Email: zahra.jalili@gmail.com

Davood Shojaeizadeh

Professor, Department of Health Education and Health Promotion, Islamic Azad University Science and Research Branch, Tehran, Iran

Received: 2019/12/18

Accepted: $2020 / 10 / 10$

Doi: 10.29252/ijhehp.8.4.255

\begin{abstract}
Background and Objective: Multiple issues in middle age make this stage of life critical and endanger women's mental health and increase the number of people with mental disorders. Women are more likely than men to have mental disorders, and middle-aged people are more likely to have these disorders than other age groups. The purpose of this study is to determine the effect of educational intervention based on the PRECEDE-PROCEED model on mental health of middleaged women referred to municipal health centers in Tehran.

Materials and Methods: A semi-experimental study was conducted using random sampling method among72 middle-aged women of selected comprehensive health houses in the city. Data gathering tools were; the general health questionnaire (GHQ-28) and a questionnaire designed based on PRECEDE Model, the validity and reliability of which had been approved prior to the study and before and after educational intervention was completed by intervention and control groups. The data were analyzed by SPSS 19 and using the statistical, Chi-square, T-test, etc. Results: The results showed that the mean age of women was 47.9. After the educational intervention, the mean score of the PRECEDE Model (Predisposing factors, enabling factors, reinforcing factors), and behavior Increased in the intervention group significantly compared to the control group $(P<0.001)$. The findings showed a significant improvement in the mean mental health score from 26.3 to 16.1 among women in the intervention group compared to the control group after imposing educational intervention $(P<0.05)$.

Conclusion: The results of the present study showed that the health education program designed based on the PRECEDE PROCEED Model is effective on the mental health of the middle-aged women.

Keywords: Mental health, PRECEDE PROCEED Model, Middle-aged women, Municipal health centers

Paper Type: Research Article.
\end{abstract}

Citation (Vancouver): Shiani M, Jalili Z, Shojaeizadeh D. The Effect of Education Based on the Precede-Proceed Model on the Mental Health of Middle -aged Women referred to Municipal Health Houses of Tehran. Iran J Health Educ Health Promot. Winter 2021;8(4): 309-323. [Persian]x

- Citation (APA): Shiani M., Jalili Z., Shojaeizadeh D. The Effect of Education Based on the Precede-Proceed Model on the Mental Health of Middle -aged Women referred to Municipal Health Houses of Tehran. Iranian Journal of Health Education \& Health Promotion., 8(4), 309-323. [Persian] 


\section{تأثير آموزش مبتنى بر مدل برسيد بِروسيد بر سلامت روان زنان ميانسال مراجعهكننده به خانهای سلامت شهردارى تهران}

\section{جكيده}

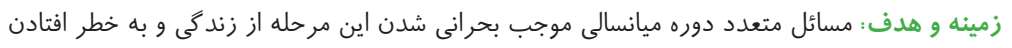

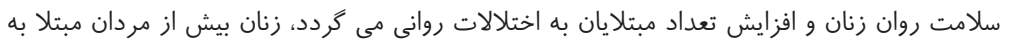

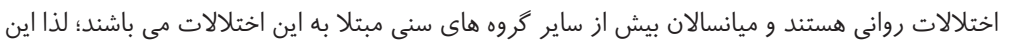

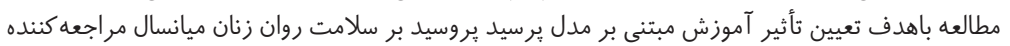

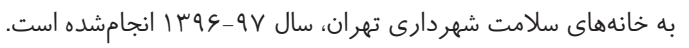

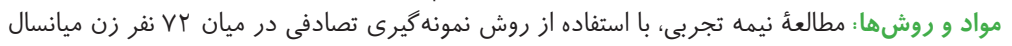

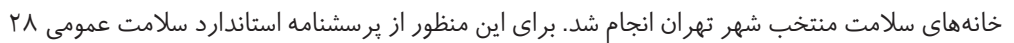

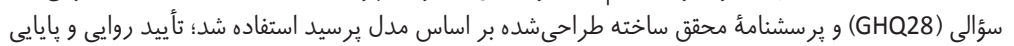

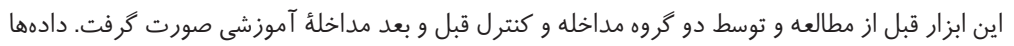

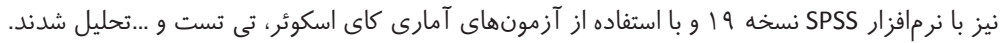

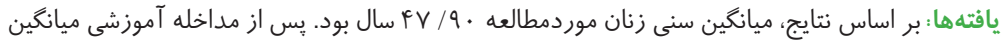

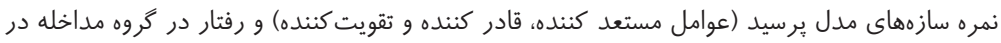

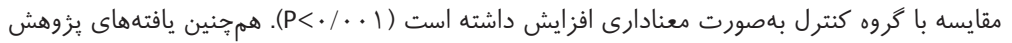

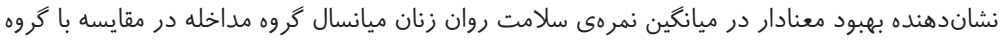

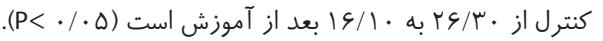

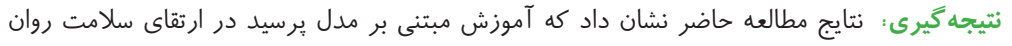
زنان ميانسال مؤثر است.

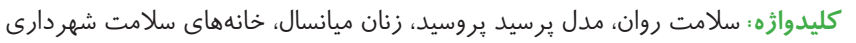
نوع مقاله : مطالعه يزوهشى.

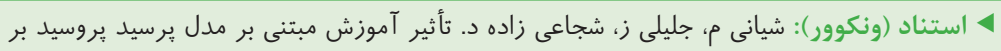

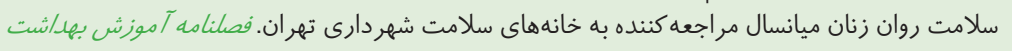

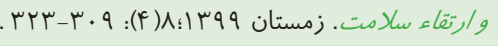

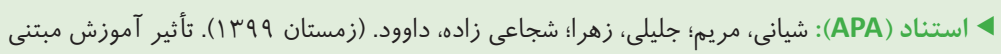

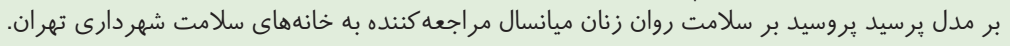

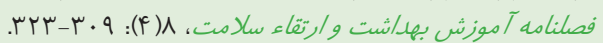

r).

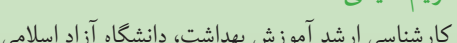

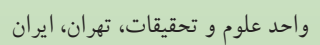

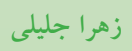

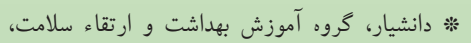

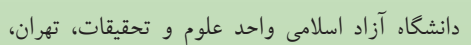
zahra.jalili@gmail.com

$$
\text { ايران.(نويسنده مسئول) }
$$

داوود شجاعى زاده

استاد، كروه آموزش بهداشت و ارتقاء سلامت، دانشكاه آزاد اسلامى واحد علوم و تحقيقات، تهران، ايران آنان

تاريخ د ريافت: تارئ | تاريخ يذيرش: 9 | 
است. دراينباره، آمارهاى جهانى بار بيمارىها، بيمارىهاى روانى

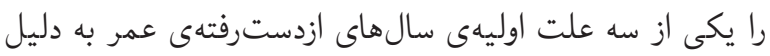

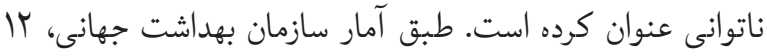
ميليون نفر از مردم جهان در سنين مختلف از بيمارىهاى شديد روانى رنج مى برند و بال ميليون نفر بيمارى خفيف روانى دارند.

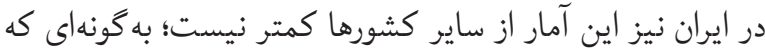
مطالعات همه گيرشناسى اختلالات روانى انجامشده در ايران، دلالت دئل

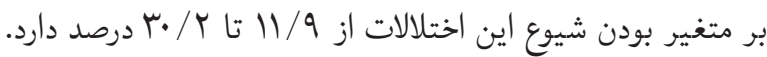

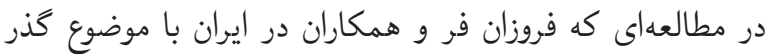
سلامت ايران به سمت بيمارى هاى مزمن بر اساس نتايج جهانى بار

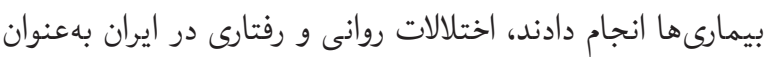

يكى از مسائل اصلى حوزنى سلامت مطرح شد (†). يثو هشكر ان سازمان جهانى بهداشت (WHO) و دانشكاء هاروارد

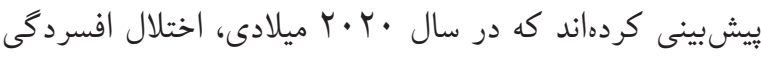
از جهارمين علت به دومين علت خواهد رسيد. اين بيشبينىها

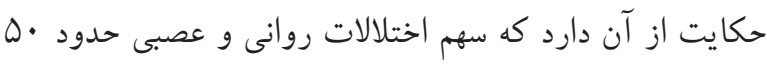
درصد افزايش مىيابد و از || درصد كنونى به حدود ها درصد

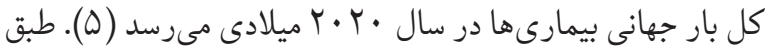
بر آوردهاى سازمان جهانى بهداشت ميزان شيوع اختلالات روانى در كشورهاى درحال توسعه رو به افزايش است. در ميان اختلالات

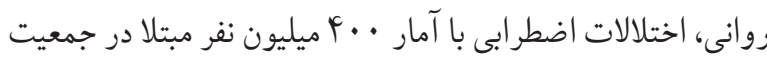

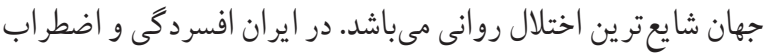

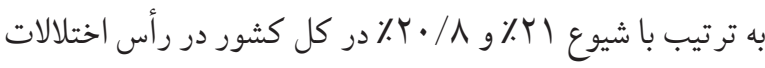
روانى قرار دارند بنا بر مطالعات انجامشده، ارتباط مستقيمى ميان

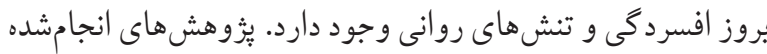
نشان مىدهد كه عامل استرس ميان زنان و مردان متفاوت بوده و

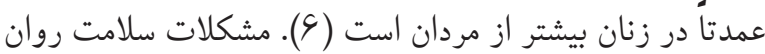

از شيوع بسيار بالايى بهخصوص در زنان برخوردار مىباشد (1).

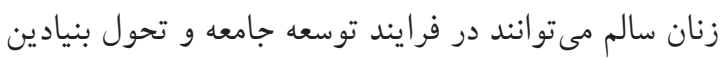
در كليه شئون و عرصههاى حيات اجتماعى سهم داشته و نقش
طبق تعريف سازمان جهانى بهداشت، (سلامت روان حالتى از بهزيستى است كه افراد را قادر مى سازد تا توانايى هاى خود را تشخيص داده،

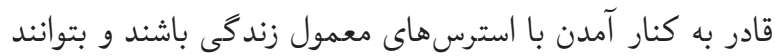
بهطور بهرهور و مؤثر كاركرده و سبب كمك به جامعه خودگردند).

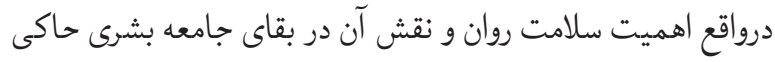
از اهميت انسان بهعنوان يك موجود اجتماعى است. اين مقوله مهم بر تمامى جنبه هاى زندگى انسان تأثيرگذار است و ارتباطى دوطرفه

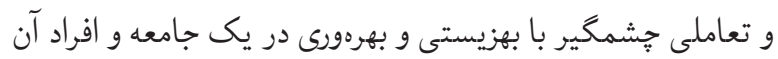
دارد ( (). روانشناسان معتقدند خصوصيات فردى، فشارهاى روانى و و هوني

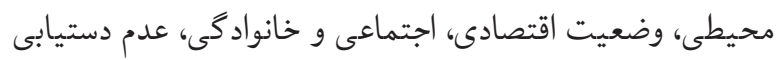
به اهداف زندگى و فقدان انكَيزه بر سلامت روانى افراد مؤثر است. مفهوم سلامت روانى، درواقع جنبهاى از مفهوم كلى سلامتى است و بر كليه روشها و تدابيرى اطلاق مىشود كه براى جلوكيرى از ابتلابه

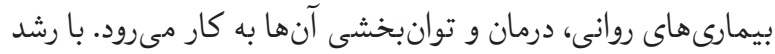
جمعيت و توسعه شهرنشينى و صنعتى شدن، بيمارىهاى روانى، در

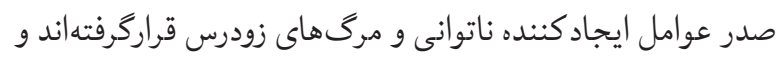

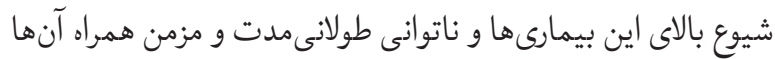
باعث شده تا اين مشكلات در تمامى جوامع بهعنوان يك اولويت

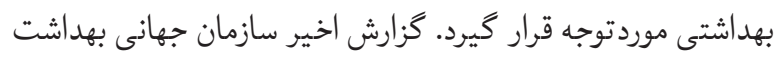

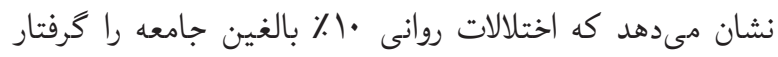

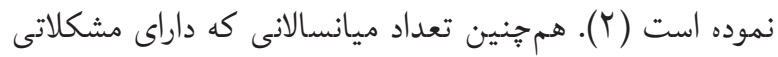
درزمينه سلامت روان هستند با نظر به برخى تعاريف سلامت روان مثل تعريف سازمان بهداشت جهانى كه سلامت روان را فقط فقدان

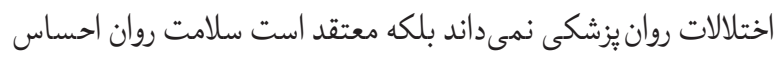

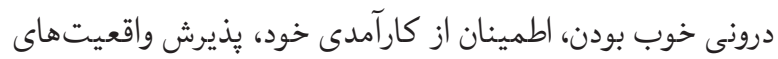

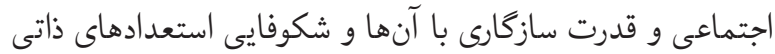

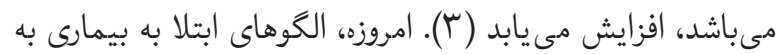

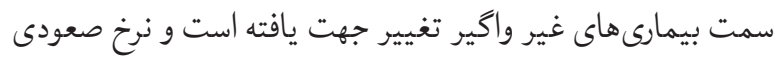

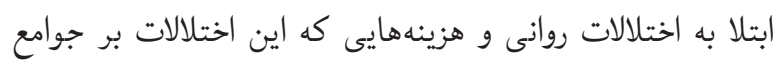
تحميل مى كنند، توجه متخصصان ارتقاى سلامت را جلب كرده 


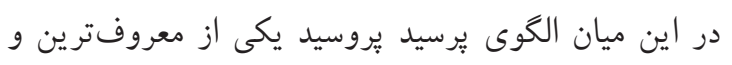

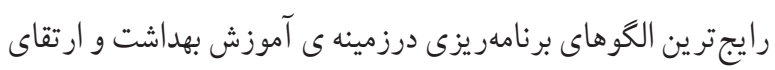

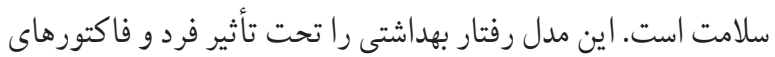

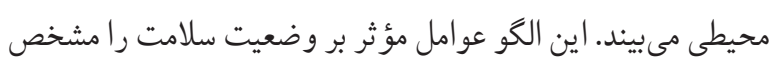

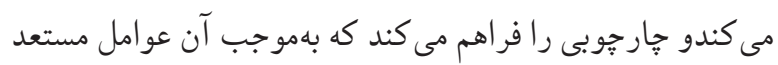
كنده (دانش، نكرش، ادراكات، باورها و...)، تقو يت كننده (تأثير ديخران، خانو اده، همسالان، كار كنان بهداشتى و ...) و قادر كنندا.

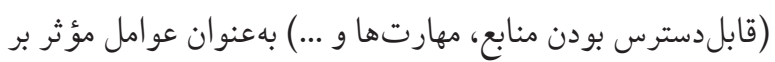

رفتار در تشخيص آموزشى تعيين مى كردند (9- - (1). الكوى يرسيد يك الكوى نظرى مؤثر جهت شناسيايى نيازها در

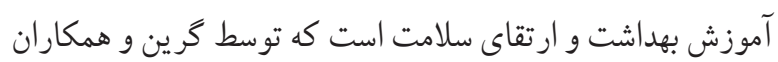

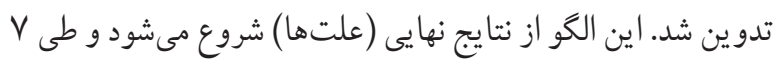

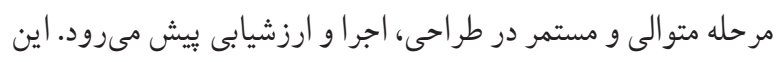

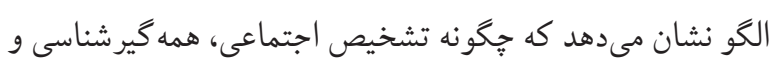

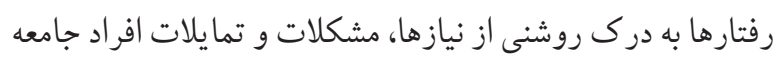

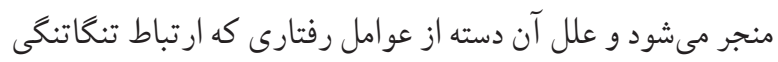

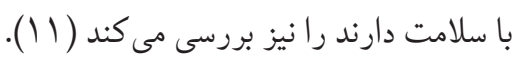

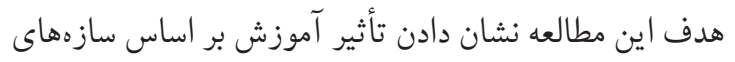

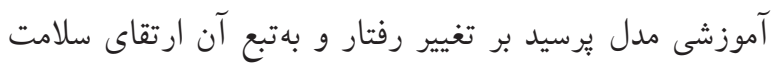

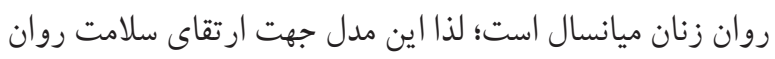
به علت كارايى بالاى آن در تغيير رفتار كه در مطالعات متعدد آندان

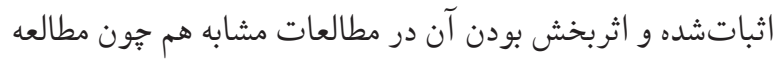

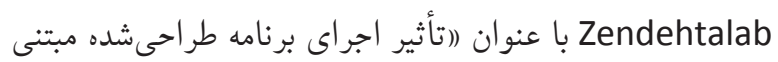

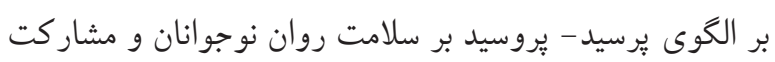

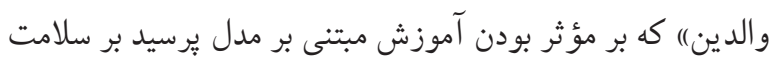

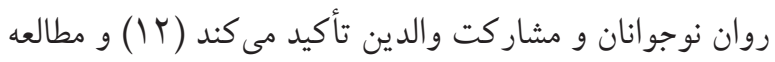

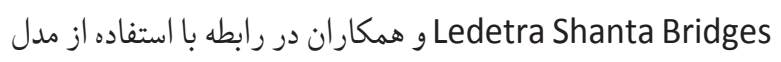
PRECEDE-PROCEED براى يبشكيرى از خودكشى و آكاهى از

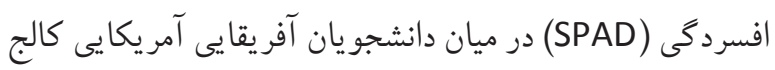

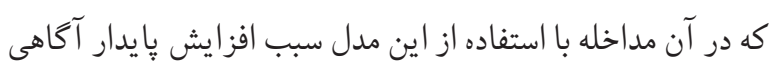

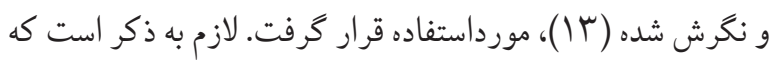

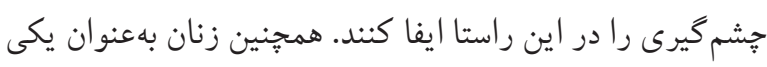

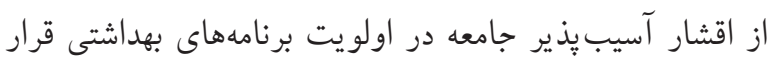

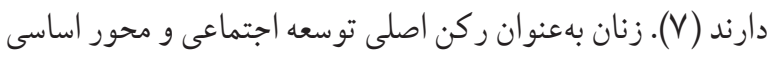

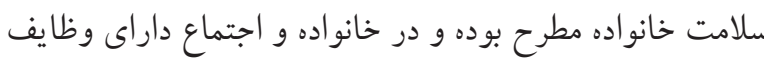
و نقشهاى مهمى هستند كه لازمه اجراى اين نقشها و و وظايف برخوردارى از سلامت كامل جسمى و روانى است (^).

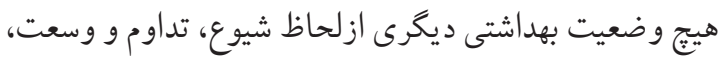
ماند مشكلات روانى و اختلالات سلامت روان مطرح نمى باشند. هم اينك بيش از •مأم ميليون نفر در سراسر دنيا از نوعى اختلال

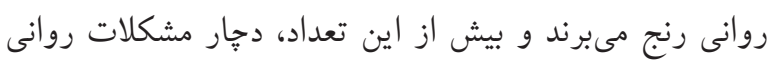

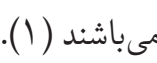
هدف از آموزش بهداشت تغيير رفتارهاى بهداشتى بهمنظور

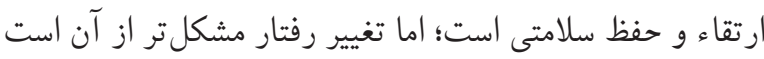
كه بتوان با آموزشهاى سنتى انتظار تحقق آن راد داشت. خصوصاً

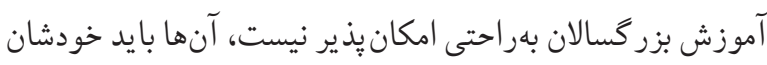

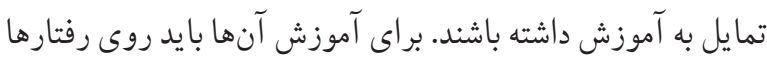

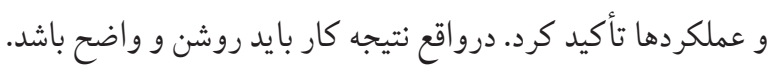

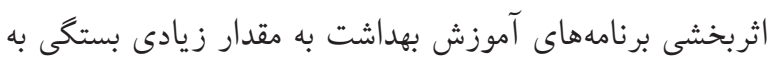

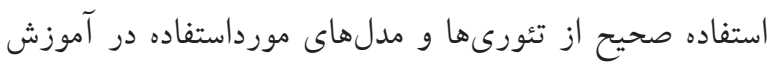

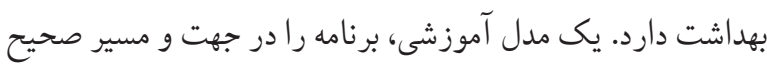

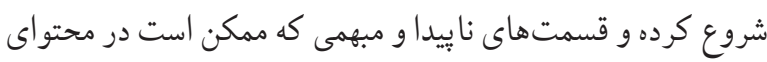
اصلى يك مداخله آموزشى وجود داشته باشد را كاهش مى مدهدي و همجنين يك جارجوبى براى اندازهيرى و ارزي يابى برنامههاى

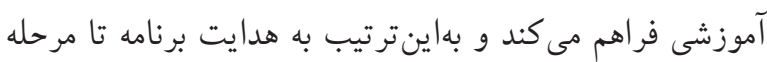

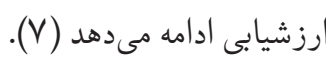
بهطور كلى در هر موردى كه از لزوم دكَّ كون كردن رفت آنتار انسان

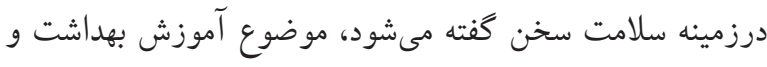

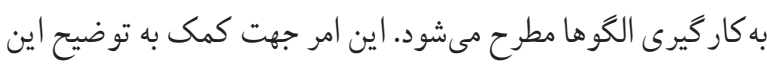

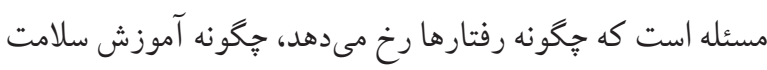

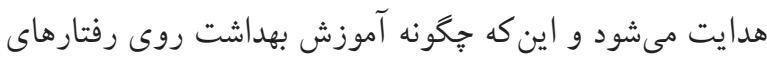
بعدى تأثير مى كذارد. 


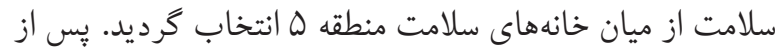
كسب اجازه از مسئولين و معرفى خود، بيان اهداف و نحوه انجام يُزوهش در واحدهاى مورديزوهش كه معيارهاى ورود به مطالعه را داشته باشند دعوت به همكارى شد. روش نمونه كيرى تصادفى جندمرحلهاى بود و VY نفر از زنان

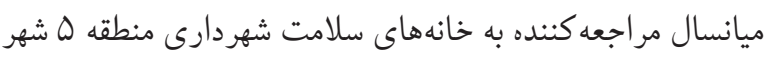

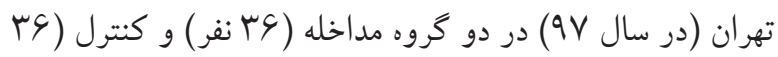
نفر) به روش نمونه گيرى تصادفى انتخاب شدند... با توجه به تعداد

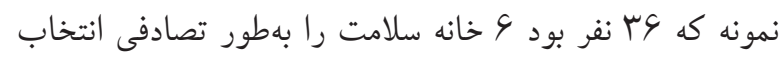

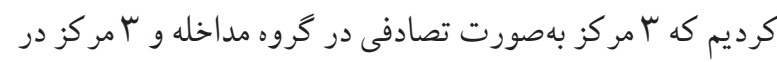

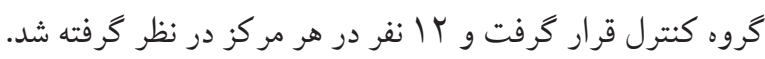
معيار ورود به مطالعه، ميانسال بودن زنان مراجعه كننده به

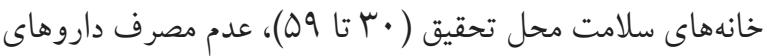
روان يزشكى (خود اظهارى)، تكميل فرم رضايت آكاهانه كتبى و

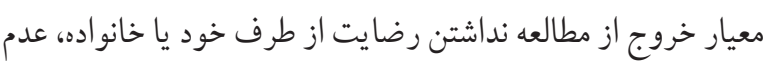

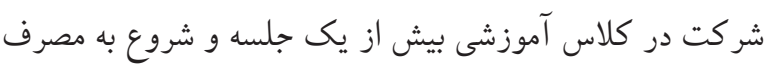
داروهاى روان يزشكى بود.

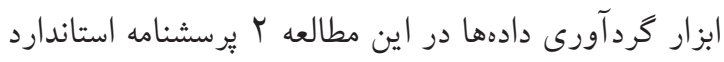
سلامت عمومى Y Tؤ ألى (GHQ28) و يرسشنامه محقق ساخته بود.

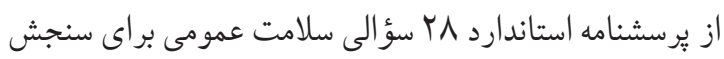
سلامت روان استفاده شد. اين برسشنامه يكى از شناخته شدهترين

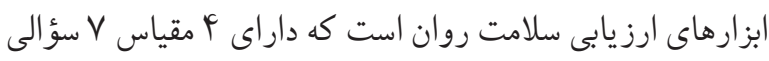

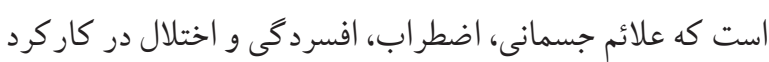

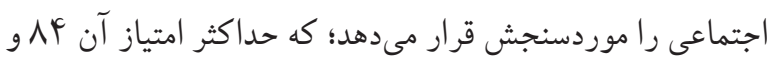
حداقل صفر است، وضعيت سلامت روانى ارتباط معكوس با امتياز اين يرسشنامه دارد يعنى با ارتقاء سلامت عمومى در افراد، امتياز اين تبرسشنامه كاهش مى يابد.

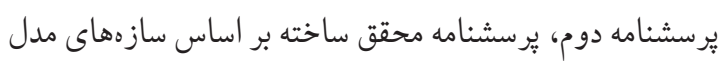

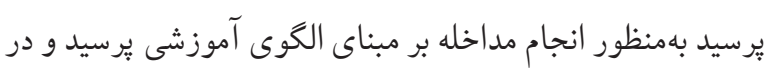

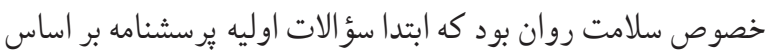
كتب و منابع معتبر و مطالعات متين و همكاران، حسينى و همكاران
فقط از بخش برسيد مدل در يُزوهش حاضر استفادهشده است. نتايج

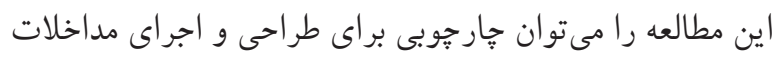

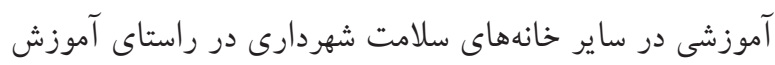
و ارتقاى سلامت روان زنان ميانسال دانست... لازم به ذكر است دهري كه فقط از بخش بِرسيد مدل در يُزوهش حاضر استفادهشده است. مو اد و روش ها مطالعه حاضر يك مطالعهى مداخلهاى از نوع نيمه تجربى قبل و بعد

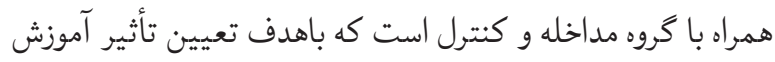

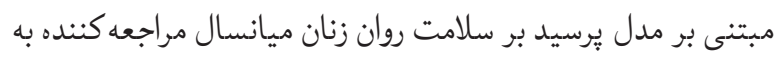

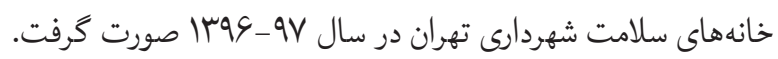
در اين ثُزوهش جامعه موردمطالعه زنان ميانسال مراجعه كننده به خانههاى سلامت شهردارى شهر تهران است كه گروه سنى ميانسال بر اساس تعريف اداره سلامت ميانسالان •ب تا ه9 سال در نظر گرفته

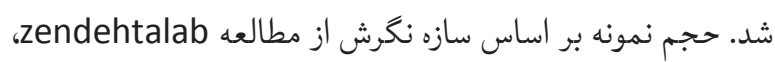

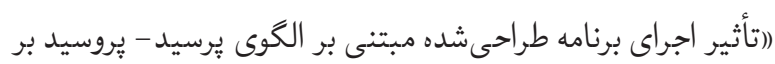

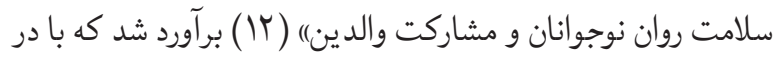
نظر گرفتن فاصله اطمينان برابر •9٪ و توان آزمون •^٪ و و احتساب احتمال • إدرصد ريزش نمونه از فرمول حجم نمونه، تعداد نمونهها در هر گروه مداخله و كنترل צץ نفر در نظر گرفته شد كه اين تعداد نمونه نزديك به تعداد نمونهى در نظر گرفتهشده در مطالعات مشابه

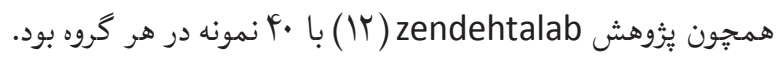

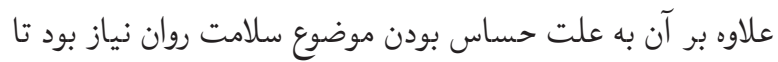

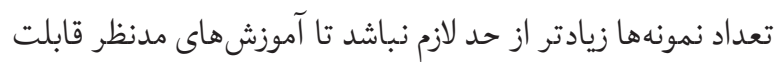

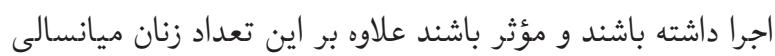
هـم كه به خانههاى سلامت مراجعه مى كردند محدود بود.

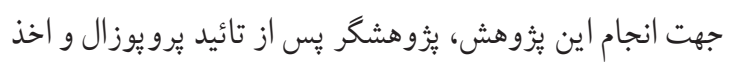

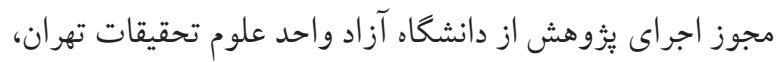

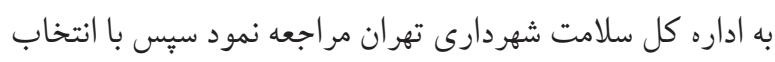

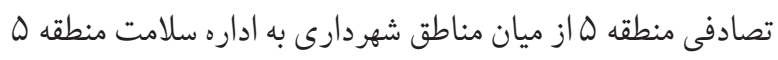
معرفى شد. پِ از هماهنكى هاى لازم بهصورت تصادفى 9 خانهى 
باعث ارتقاء رفتار سالم مى شوند مطرح شد و با سؤال در رابطه با

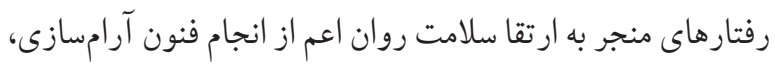

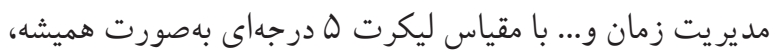

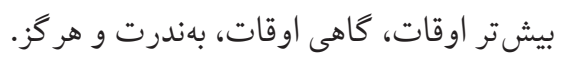

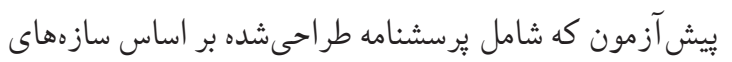

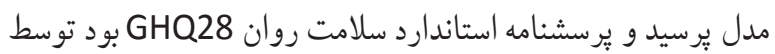
زنان ميانسال مراجعه كننده به خانهاى سلامت محل تحقيق كه واجد شرايط مطالعه بودند تكميل كرديد. برسشناهه إي تكميلشده

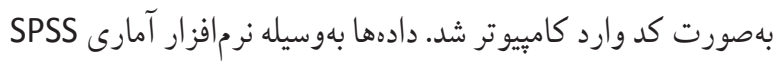

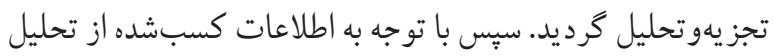

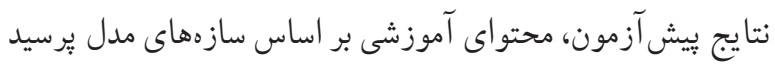

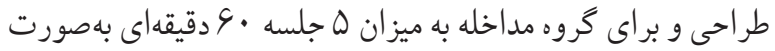

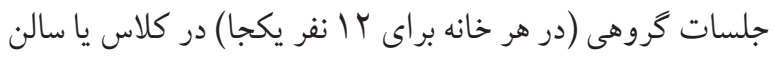

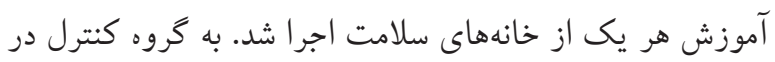
طول مداخله هيج آموزشى داده نشد. محتوا با توجه به موضوعات مؤثر و مرتبط با سلامت روان إندان افراد بر اساس مطالعات انجامشده و تجارب ارائهده در مقالات

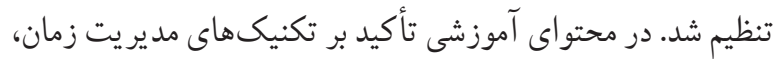
مديريت استرس، تابآورى و برقرارى ارتباط مناسب بر اساس

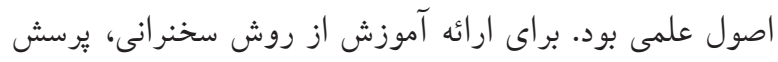

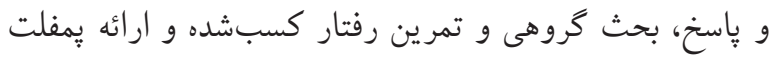

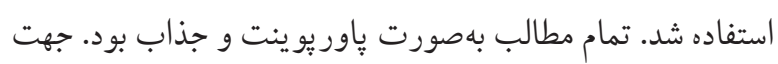

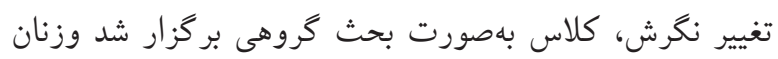

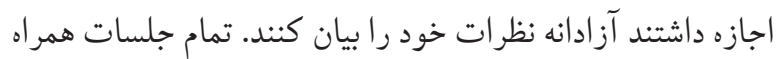

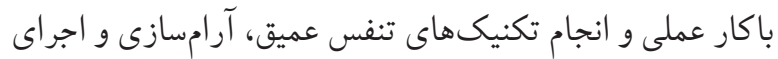

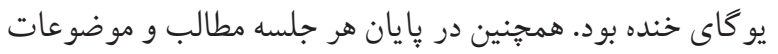

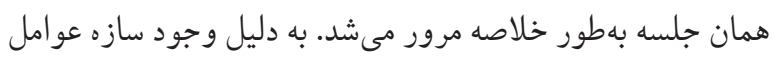

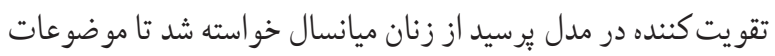

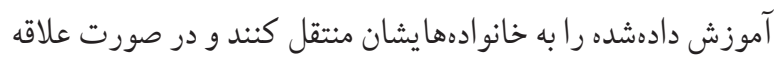
مى توانستند دوستان يا آشنايان خود را براى شركت در جلسات بعدى همراه خود بياورند. جهت بهبود وضعيت سازه عوامل قادر
وزنده طلب طراحى شد. سبس روايى آن با استفاده از شيوه روايى محتوايى (توسط جمع بندى نظرات • ا نفر از اساتيد) احراز شد.

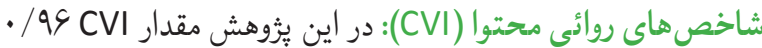

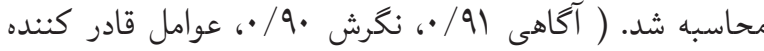

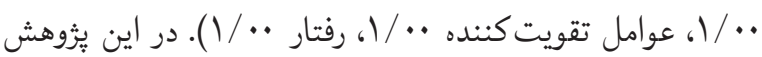

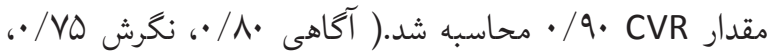

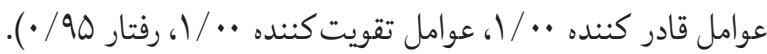
براى تعيين پايايى يرسشناهه محقق ساخته مبتنى بر ثرسيد،

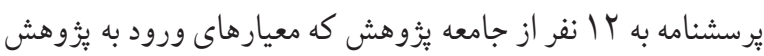

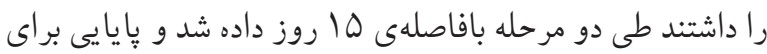
هر كدام از متغيرها بالاى V/ • بهدست آمد.

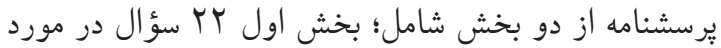

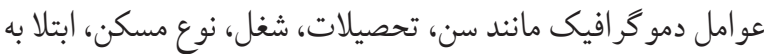
بيمارى خاص، سابقه شخصى و خانوادگى مصرف دارو و و يا مراجعه به روان يزشك، داشتن اضافهوزن، ميزان فعاليت بدنى و سؤ الاتى ازايندست. بخش دوم يرسشنامهى مدل يرسيد حاوى •و سؤال

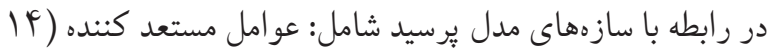
سؤال آكاهى با مقياس بله و خير كه منظور همان دانش بهدست آمده در مورد سلامت روان از طريق درك فردى يا ساير ابزار اطلاعاتى و يا از طريق آموزش است و IV سؤال نكرش شامل باون باورهاى

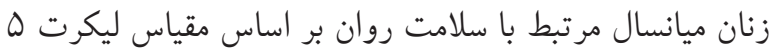

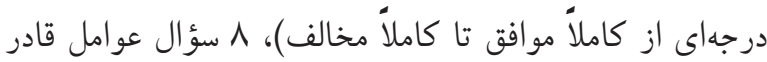

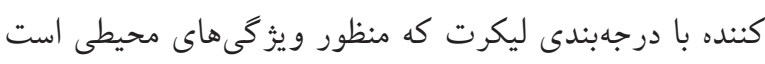

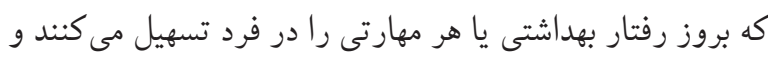

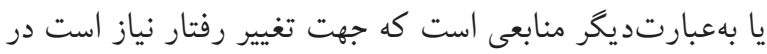

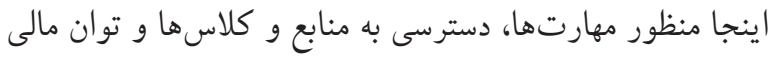

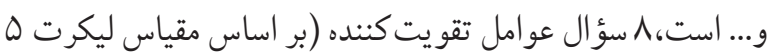

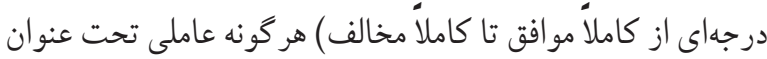

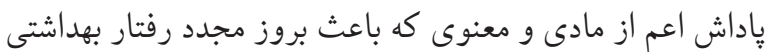

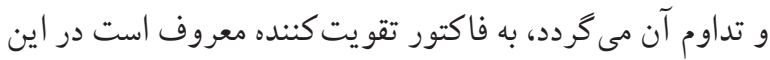
مطالعه عواملى از قبيل حمايت و تشويق خانو اده، دوستان و...كه 

زمان جلسهى بعدى كلاس حتماً تكنيك آموزش دادهشده را تمرين نمايند لذا براى اطمينان از انجام تمر ينات در منزل و تشويق زنان ميانسال از آنها خواسته شد دفعات انجام تكنيكها راثبت آنبت نمايند

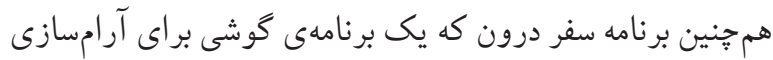

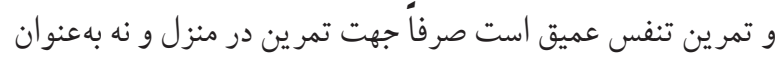
بخشى از آموزش معرفى شد. عناوين و سرفصل مداخله آموزشى: آشنايى شركت كنند كان آدان با تعريف سلامت روان، آشنايى باهميت سلامت روان، آشنايى با

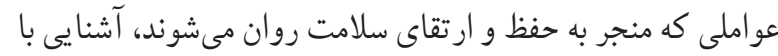
جدول ا. عناوين و سرفصل مداخله آموزشى

روش تدريس

\begin{tabular}{|c|c|c|}
\hline جلسه اول & نكرش آكاهى & 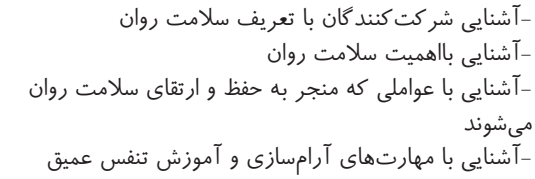 \\
\hline جلسه دوم & تقويت كننده & 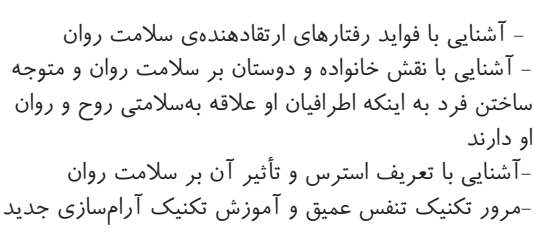 \\
\hline
\end{tabular}

-شر كت كنند كان بتوانند اهميت سلامت روان را بيان كنند

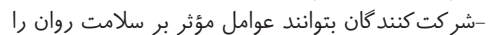
بيان كنيد

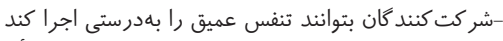

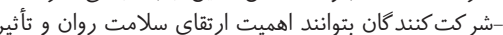
شر كت در كلاس هان آموزشى را شرح دهد.
سخنر انى برس و و باسخ

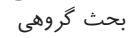
تمرين تنفس عميق

- شر كت كننده بتواند فوايد رفتارهاى ارتقادهندهى سلامت روان را بيان كند - شركت كننده نقش اطر افيان را در رابطه با سلامت روان

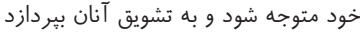

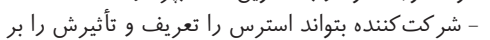

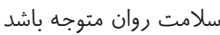

- تكنيك تنفس عميق ران ماد باد بادرستى انجام دهد و تكنيك

جديد را ياد بنغيرد عميق را بلهدرستى انجام دهد و تكنيك
سخنرانى يرسش و پاسخ بحث كروهى تمرين تكنيك تجرون

\begin{tabular}{|c|c|c|c|}
\hline جلسه سوم & 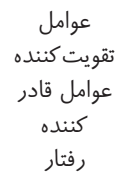 & 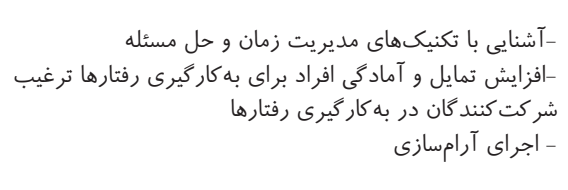 & 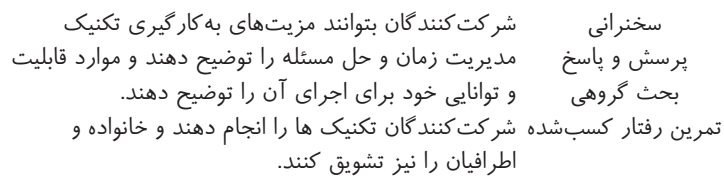 \\
\hline جلسه جهارم & 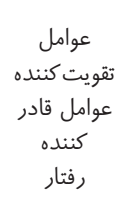 & 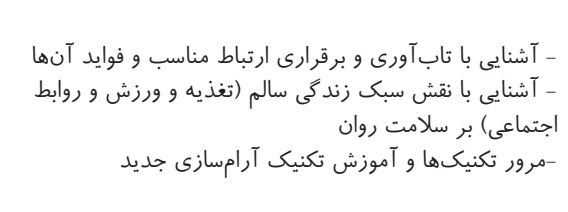 & 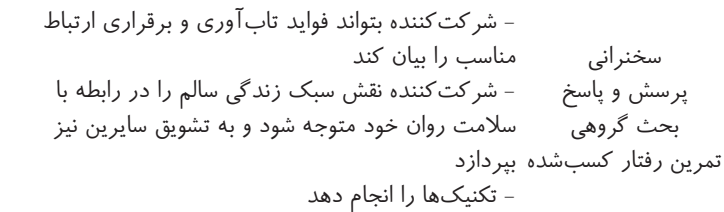 \\
\hline
\end{tabular}

-مرور مطالب آموزشى حيطه عوامل مستعد كننده (آكاهى و

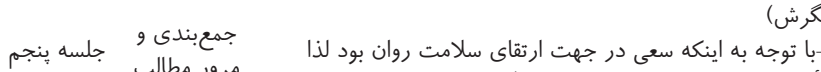

- شركت كنند كان اصول انجام صحيح تكنيكها جهت ارتقاى رواى

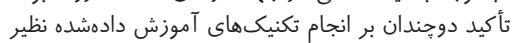

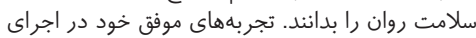
تكنيكها را از جلسه اول تاكنون را بيان نمايند

سخنر انى

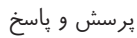
بحث كروهى و باسخ

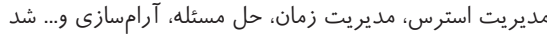




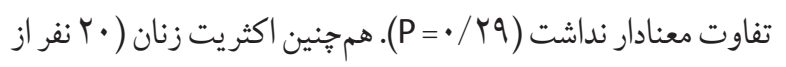

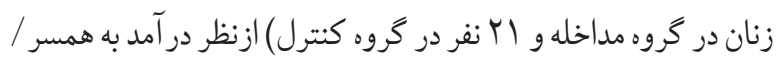

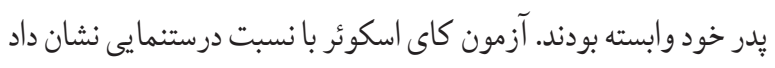

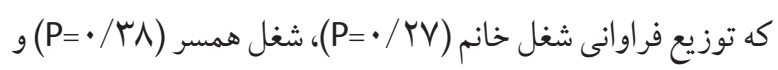

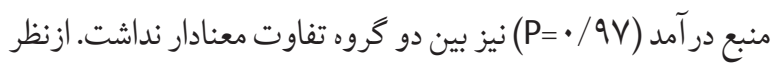
شغل، بيشترين فراوانى هر دو گروه در گروه زنان خانهدار قرار داشتند. ازنظر شغل همسران، در هر دو گروه بيشترين آنان بازنشسته بودند. توزيع فراوانى وضعيت تأهل در دو گروه كاملاً يكسان بود.

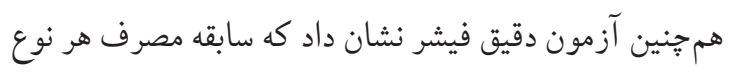

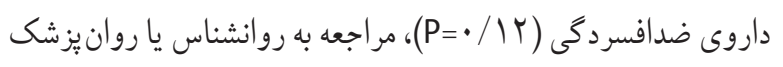
(P= • ب / M )

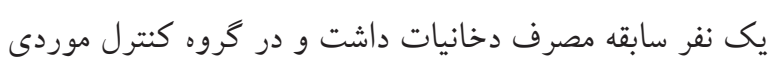

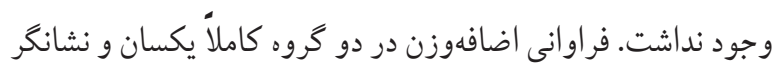

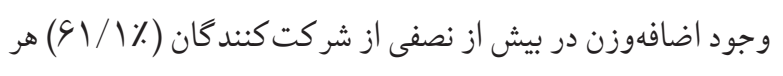

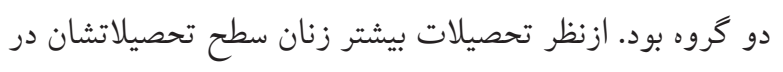

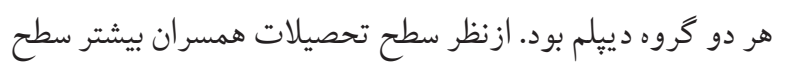

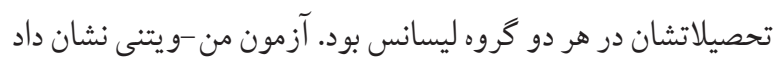

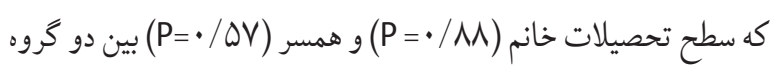

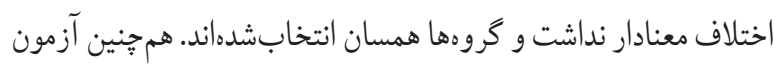

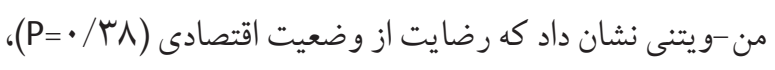

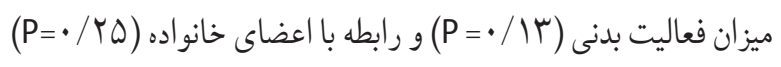

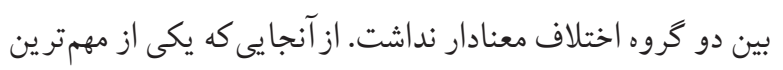
ويز گى هاى مطالعات تجربى همسانسازى متغير هاى موردمطالعه

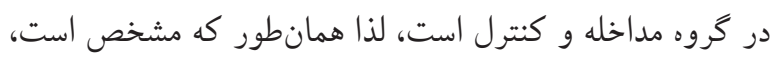

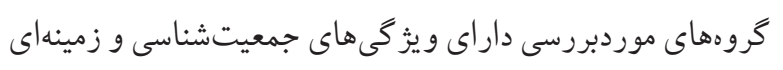

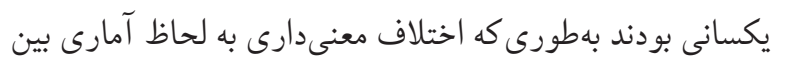

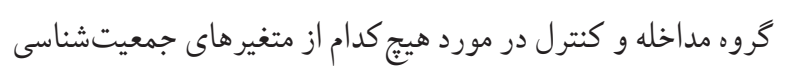

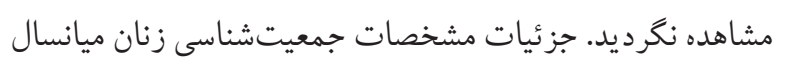

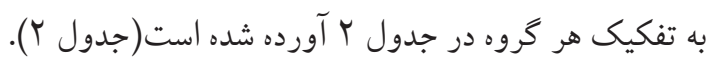
نتايج يزوهش نشان مىدهد قبل از مداخله بين ميانگين نمرات

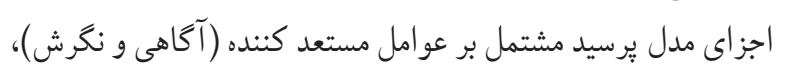

ارزشيابى از ميزان كار آيى و تأثير برنامه آموزشى در مرحله

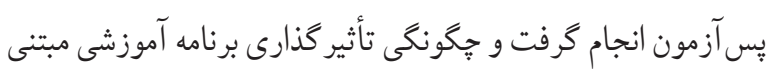

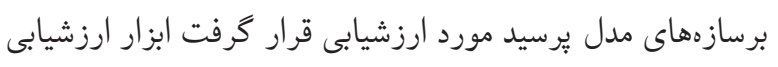

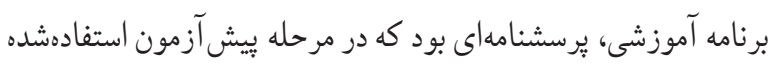

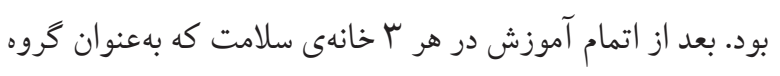

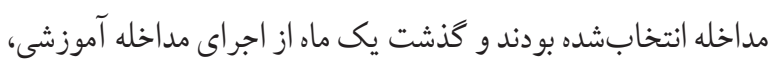

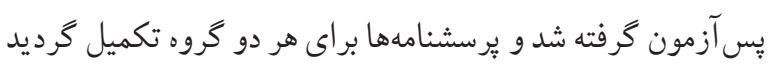

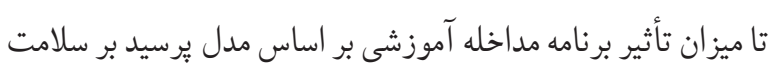

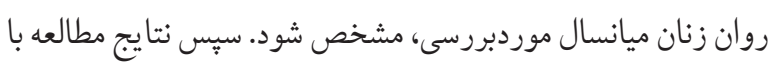

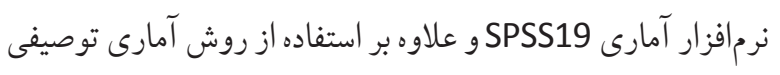

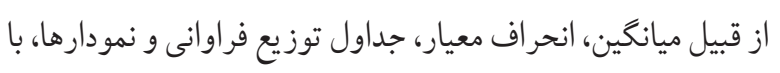

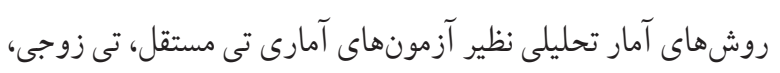
آزمون كاى دو و آناليز واريانس تحليل شد. رون.

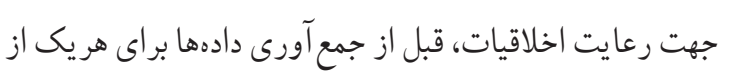

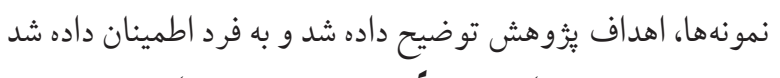
كه اطلاعات بهدست آمده كاملاً محرمانه بوده و جمع آورى اطللاعات تنها از افرادى صورت كرفت كه تمايل به شركت داشتند؛ و همجنِين جهت محروم نماندن كروه كنترل از موضوعات آموزشى، جلسات

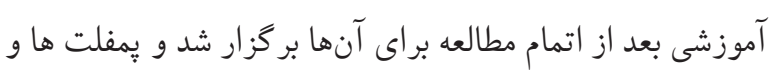
تراكت هاى طر احىشده در اختيار آنها قرار كرفت.

\section{يافتهه ها}

در يُوهش حاضر درمجموع VT زن ميانسال مراجعه كننده به

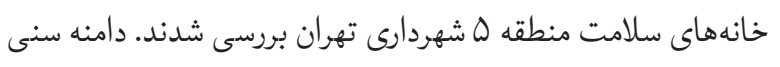

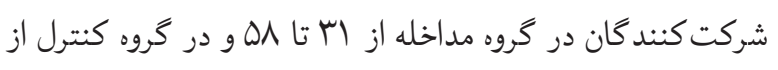

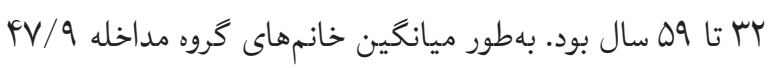

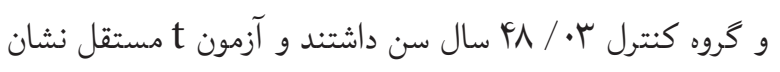

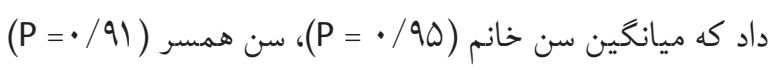
بين دو گروه اختلاف معنادار نداشت.

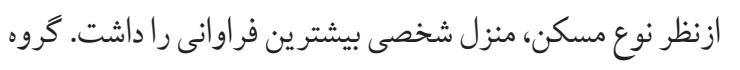

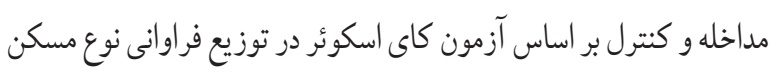


جدول ץ. اطلاعات دموگر افيك شر كت كنندگًان در مطالعه

\begin{tabular}{|c|c|c|c|c|c|c|}
\hline \multirow{2}{*}{ P-value } & \multicolumn{2}{|c|}{ كروه كنترل } & \multicolumn{2}{|c|}{ كروه مداخله } & \multirow{2}{*}{ متغير } & \multirow{2}{*}{ متغير } \\
\hline & درصد & تعداد & درصد & تعداد & & \\
\hline \multirow{3}{*}{1} & $91 / 9$ & $\mu$ & $91 / 4$ & 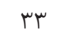 & متأهل & \multirow{3}{*}{ وضعيت تأهل } \\
\hline & $0 / 9$ & r & $\Delta / 4$ & r & بيوه & \\
\hline & $r / \Lambda$ & 1 & $r / \Lambda$ & 1 & مطلقه & \\
\hline \multirow{4}{*}{$\cdot / r V$} & $\Lambda / r$ & r & $\Lambda / r$ & $r$ & كارمند & \multirow{4}{*}{ شغل خانم } \\
\hline & $1 \% / 9$ & $\Delta$ & $r / \Lambda$ & 1 & آزاد & \\
\hline & $19 / V$ & 4 & $r V / \Lambda$ & 1. & بازنشسته & \\
\hline & $91 / 1$ & $r r$ & $91 / 1$ & $r r$ & خانهدار & \\
\hline \multirow{4}{*}{$\cdot / \mu \wedge$} & $r \cdot / \mu$ & 1. & $r \mid / r$ & v & كارمند & \multirow{4}{*}{ شغل همسر } \\
\hline & $r V / r$ & 9 & $r V / r$ & 9 & آزاد & \\
\hline & $r \varepsilon / f$ & ir & $01 / 0$ & iv & بازنشسته & \\
\hline & 4 & $r$ & $\cdot$ & $\cdot$ & بيكار & \\
\hline \multirow{2}{*}{$\cdot / r q$} & $r r / r$ & $\wedge$ & 每 & ir & استيجارى & \multirow{2}{*}{ نوع مسكن } \\
\hline & $V V / \Lambda$ & rᄉ & $s 9 / \mathrm{V}$ & $r F$ & شخصى & \\
\hline \multirow{4}{*}{$\cdot / 9 V$} & $\mu \mu / \mu$ & ir & $\mu \mu / \mu$ & ir & اشتغال & \multirow{4}{*}{ منبع در آمد } \\
\hline & $\Delta \Lambda / r$ & rI & $\Delta \Delta / 9$ & $r$. & وابسته به همسر/:در & \\
\hline & $r / \Lambda$ & 1 & $r / \Lambda$ & 1 & فروش يا اجاره اموال & \\
\hline & $\Delta / \&$ & r & $\Lambda / r$ & $r$ & ساير & \\
\hline \multirow{4}{*}{$\cdot / \wedge \Lambda$} & $1 \% / \Lambda$ & $\Delta$ & $11 / 1$ & r & زير دييلم & \multirow{4}{*}{ سطح تحصيلات خانم } \\
\hline & $\Delta r / \Lambda$ & 19 & $\Delta \Delta / \Delta$ & $r$. & دييلم & \\
\hline & $r \cdot / 9$ & 11 & $r \cdot / 4$ & 11 & ل ل ليسانس & \\
\hline & $r / \Lambda$ & 1 & $r / \Lambda$ & 1 & فوقليسانس & \\
\hline \multirow{5}{*}{$\cdot / \Delta v$} & $9 / 1$ & $r$ & $9 / 1$ & $r$ & زير دييلم & \multirow{5}{*}{ سطح تحصيلات همسر } \\
\hline & $r \cdot / r$ & 1. & $r q / r^{p}$ & ir & دييلم & \\
\hline & FN/D & 19 & $r q / p$ & ir & ليسانس & \\
\hline & $9 / 1$ & $r$ & $|r /|$ & $r$ & فوقليسانس & \\
\hline & $r$ & 1 & . & . & دكترى & \\
\hline \multirow{3}{*}{$\cdot /$ / } & 每 & ir & $r V / \Lambda$ & 1. & بله & \multirow{3}{*}{ رضايت از وضعيت اقتصادى } \\
\hline & $\Delta \Lambda / F$ & rl & $\Delta \Delta / \Delta$ & $r$. & تا حدودى & \\
\hline & $\Lambda / r$ & $r$ & $19 / \mathrm{V}$ & 4 & خير & \\
\hline \multirow{4}{*}{$\cdot / 1 \mu$} & 每 & ir & $r r / r$ & $\wedge$ & هفتهاى ب بار و بيشتر & \multirow{4}{*}{ ميزان فعاليت بدنى } \\
\hline & $r r / r$ & $\wedge$ & $r r / r$ & $\wedge$ & هفتهاى 1- r مرتبه & \\
\hline & $r G / r$ & ir & $r \cdot / \varsigma$ & 11 & كاهى اوقات & \\
\hline & $\Lambda / r$ & r & ro & 9 & اصلاً & \\
\hline \multirow{3}{*}{$\cdot / r \Delta$} & $V V / \Lambda$ & r^ & ş/V & re & خوب & \\
\hline & $r r / r$ & $\wedge$ & $r V / V$ & 1. & متوسط & رابطه با اعضاى خانواده \\
\hline & $\cdot$ & . & $\Delta / 9$ & $r$ & ضعيف & \\
\hline$\cdot / \Delta \mathrm{V}$ & $19 / 4$ & $\checkmark$ & ro & 9 & ك خاص & \\
\hline.$/ 1 r$ & $\cdot$ & . & $\Lambda / r$ & r & روى ضدافسردگى & سابقه مصرف \\
\hline$\cdot / 1 \wedge$ & $r / \Lambda$ & 1 & $11 / 1$ & r & يا روانيزشى & مر مراجعه بـ \\
\hline$\cdot / r 1$ & $11 / 1$ & r & $r r / r$ & $\wedge$ & شناس يا روانيزشك & سابقه قبلى مرا. \\
\hline 1 & $41 / 1$ & rr & $91 / 1$ & re & 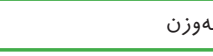 & \\
\hline .10 & . & . & $r / \Lambda$ & 1 & & \\
\hline
\end{tabular}




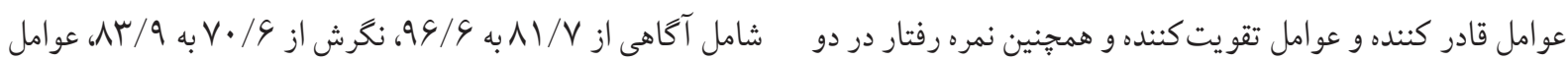

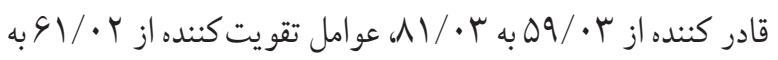

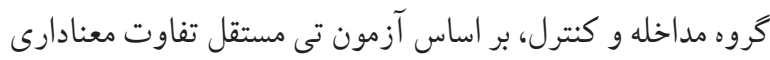

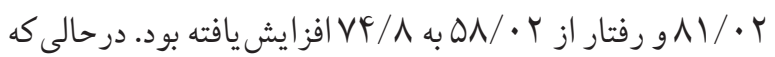

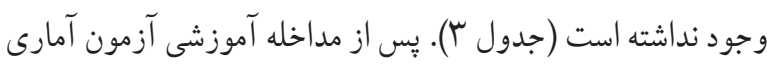

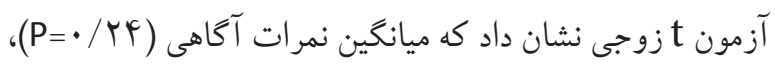

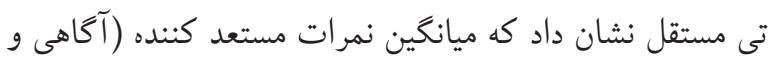

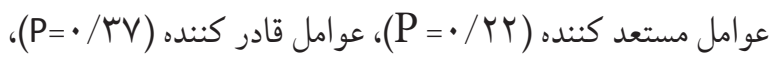

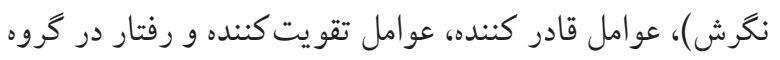

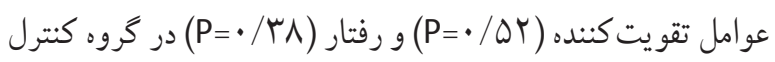

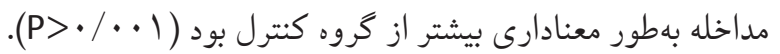

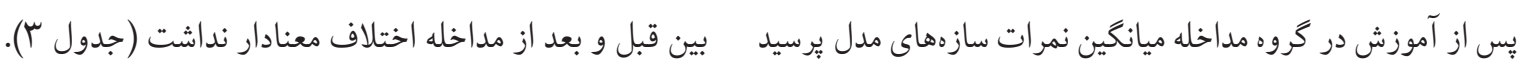
جدول س. مقايسه ميانگين نمرات آكَاهى، نگرُش، عوامل قادر كننده، عوامل تقويت كننده و رفتار قبل و بعد از مداخله بين دو گروه

\begin{tabular}{|c|c|c|c|c|c|c|}
\hline \multirow{2}{*}{ P-value } & \multicolumn{2}{|c|}{ گروه كنترل } & \multicolumn{2}{|c|}{ گرووه مداخله } & \multirow{2}{*}{ زمان آزمون } & \multirow{2}{*}{ متغير } \\
\hline & انحراف معيار & ميانكين & انحراف معيار & ميانكين & & \\
\hline$\cdot / V^{F}$ & $1 \cdot / 9$ & $\Lambda \cdot / \Lambda$ & $1 F / \mu$ & $\wedge 1 / \mathrm{V}$ & قبل از مداخله & \multirow{2}{*}{ آ آكاهى } \\
\hline$<\cdot / \cdots+1$ & $9 / 9$ & $V 9 / 4$ & $r / \mu$ & $94 / 4$ & بعد از مداخله & \\
\hline$\cdot / \pi s$ & $V / 9$ & $S N / T$ & $1 \cdot / 1$ & $V \cdot / 4$ & قبل از مداخله & \multirow{2}{*}{ 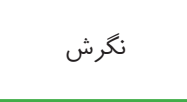 } \\
\hline$<\cdot / \cdot \cdot 1$ & $\mathrm{~V} / \Lambda$ & $99 / 1$ & $s / 1$ & $\wedge r / q$ & بعد از مداخله & \\
\hline.$/ 14$ & $11 / 1$ & $s 1 / \mu$ & $1 r / \Lambda$ & $\Delta q / \cdot r$ & قبل از مداخله & \multirow{2}{*}{ عوامل قادر كننده } \\
\hline$<\cdot / \cdot \cdot 1$ & $1 r / 0$ & $91 / 9$ & $\Lambda / \Lambda$ & $11 / \cdot r$ & بعد از مداخله & \\
\hline .101 & $1 r / 1$ & $s \mu / \cdot r$ & $1 \pi / v$ & $S 1 / \cdot r$ & قبل از مداخله & \multirow{2}{*}{ عوامل تقويت كننده } \\
\hline$<\cdot / \cdot \cdot 1$ & $1 r / F$ & $S Y / S$ & $V / 9$ & $11 / \cdot r$ & بعد از مداخله & \\
\hline.$/ 1 \Delta$ & $1 \pi / 1$ & $9 \cdot 10$ & $1 f / r$ & $\Delta N / \cdot r$ & قبل از مداخله & \multirow{2}{*}{ فتار } \\
\hline$<\cdot / \cdots 1$ & $1 r / F$ & $\Delta 9 / \Lambda$ & $1 \cdot / 1$ & $V F / \Lambda$ & بعد از مداخله & \\
\hline
\end{tabular}

همجنين در اين مطالعه در راستاى هدف كلى يُزوهش بهمنظور شماره f مشخص هست، آزمون t مستقل نشان داد كه ميانكين نمره

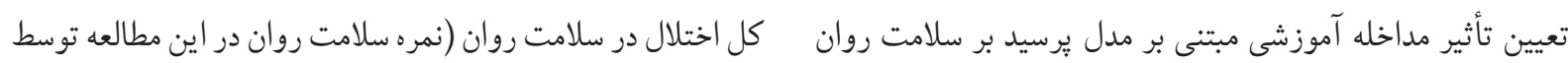

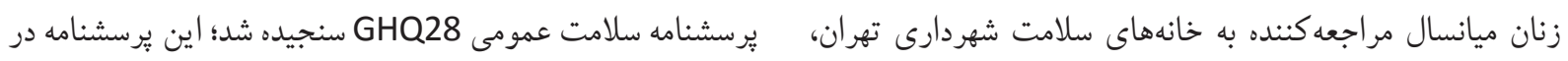

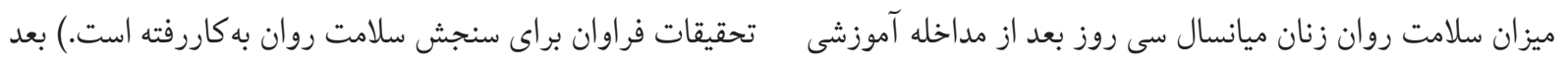

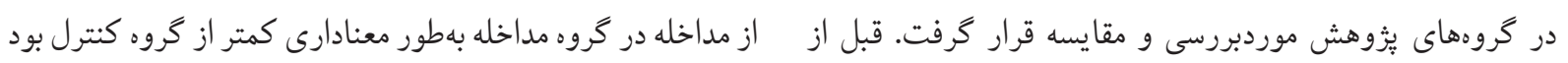

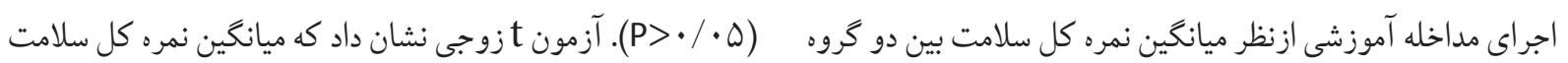

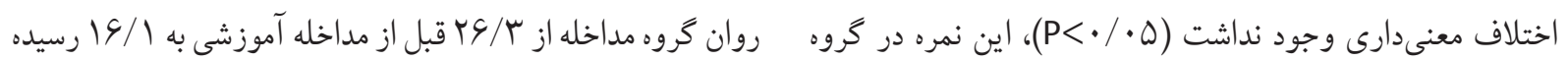

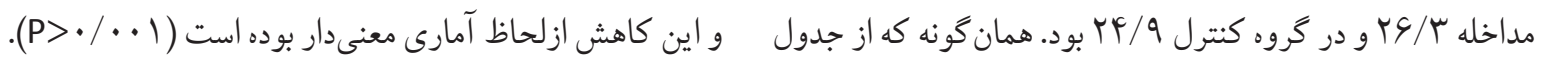
جدول عا. مقايسه ميانگين نمره كل اختلال در سلامت عمومى (سلامت روان) قبل و بعد از مداخله بين دو گر وه

\begin{tabular}{|c|c|c|c|c|c|}
\hline \multirow[b]{2}{*}{ P-value } & \multicolumn{2}{|c|}{ كروه كنترل } & \multicolumn{2}{|c|}{ كروه مداخله } & \multirow{2}{*}{ نمره كل اختلال در سلامت } \\
\hline & انحراف معيار & ميانغين & انحراف معيار & ميانغين & \\
\hline.$/ \Delta \Delta$ & $V / q$ & $r F / q$ & $r / I r$ & $r \varphi / \mu$ & قبل از آموزش \\
\hline$<\cdot / . .1$ & $\Delta / \Lambda$ & $r s / 9$ & $V / \mathcal{A}$ & $19 / 1$ & بعد از آموزش \\
\hline
\end{tabular}


Ledetra Shanta Bridges است. در اين مورد مى توان به مطالعات و همكاران در رابطه با استفاده از مدل PRECEDE-PROCEED براى ييشخيرى از خود كشى و آكاهى از افسردگى (SPAD) در ميان

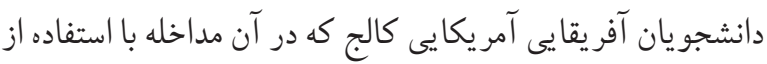

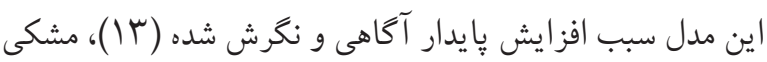

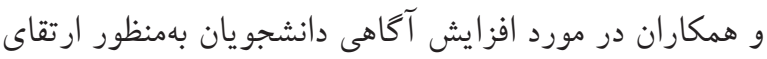

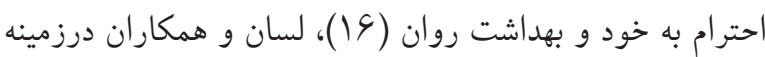

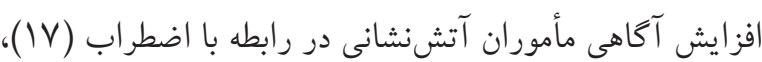

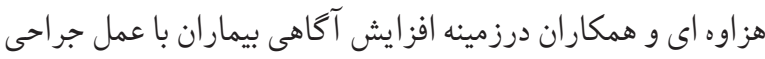

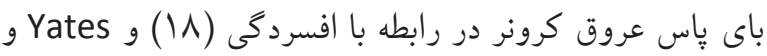

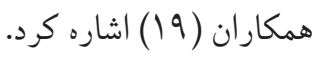
همجنين يافتهاى مطالعهى اخير نشان داد كه ميانگين نمرهى

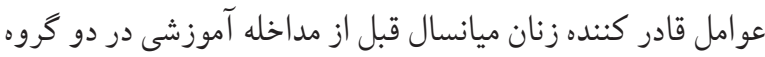
مشابه است؛ اما ميانكين اين متغير بعد از آموزش در كروه مداخد مداخله نسبت به گروه كنترل افزايش معنادار يافته است. اين تغييرات

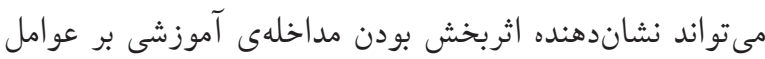
قادر كننده باشد. نتايج مطالعات فتحى زاده و همكاران (· •(Y)، متين و همكاران (YT) ودادى يور و همكاران با عنوان ((بكار

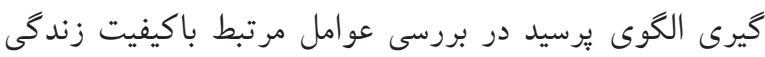

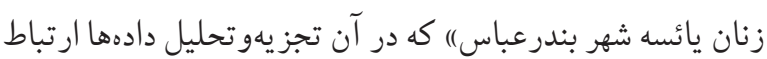
آمارى معنىدارى رابين كيفيت زندكى زنان با عوامل قادر كننده دئه

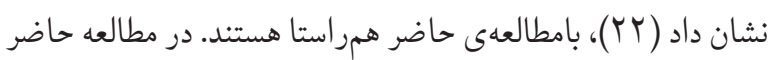

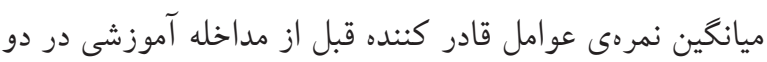
كروه تفاوت معنىدارى نداشت و بعد از مداخله در گروه مداخله افزايش يافت و ميان دو گروه اختلاف معنىدار يبدا شد.

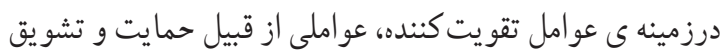

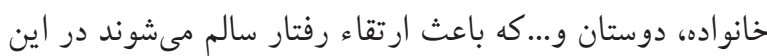

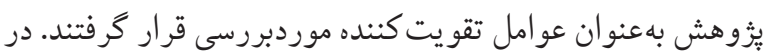

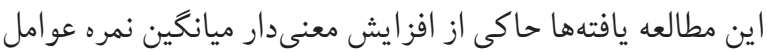

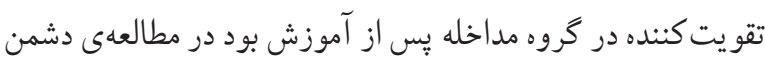

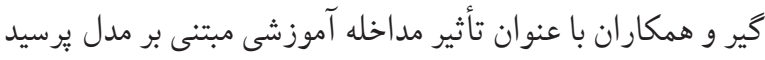

مطالعات مختلف نقش مؤثر آموزش را بر مبناى مدلهاى مختلف

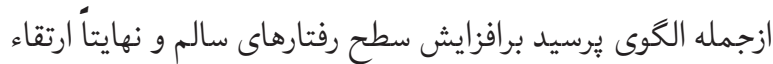
سامت ثابت كردهاند. اين مطالعه باهدف تعيين تأثير مداخله آموزشى ئى برسي مبتنى بر مدل يرسيد بر سلامت روان زنان ميانسال مراجعه كننده به خانههاى سلامت شهردارى تهران انجام شدو يافته هاى مطالعه نشان داد كه با استفاده از اين مدل مى توان تفاوت معنادارى در وضعيت سلامت روان به وجود آورد. كارايى مدل يرّسيد در ايجادو ارتقار رفتارها در جِندين مطالعه

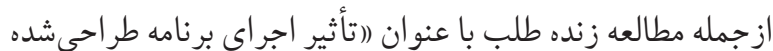
مبتنى بر الكوى يرسيد - يروسيد بر سلامت روان نوجوانان و مشاركت

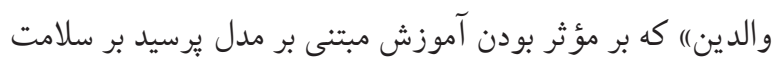

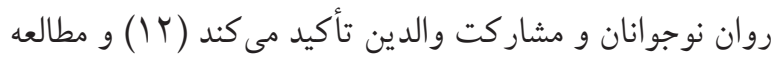
شر يفى راد و همكاران با عنوان (اثربخشى مداخله آموزشى مبتنى مونى بر الخوى يرسيد بر سطح استرس (تنش) سالمندان مراجعه كننده

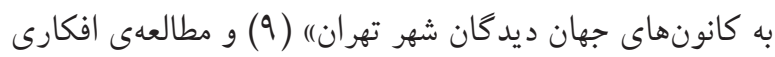
و همكاران تحت عنوان (اتأثير مداخله آموزشى بر اساس مدل هدل يرسيد - يروسيد بر ارتقاء كيفيت زندگى سالمندان در فرهنگسراى

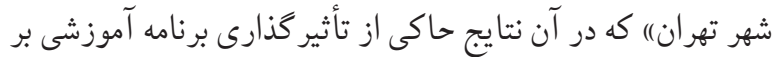

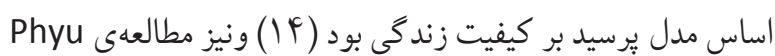
Hnin Hlaing مطالعه حاضر نشان داد كه گروه مداخله نسبت به كروه كنترل در بعد عوامل مستعد كننده (آكاهى و نكرش)، قادر كننده و تقو يت كننده

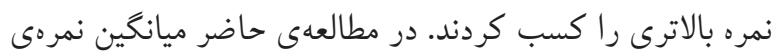

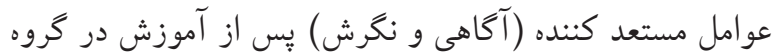

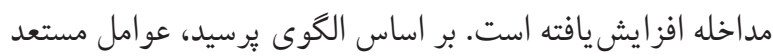

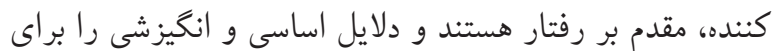

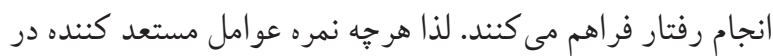

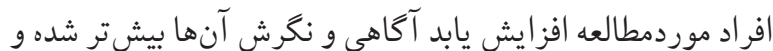
سبب تسهيل انجام رفتارهاى سودمند مدنظر در يُزوهش مى گرددد. اين موضوع در ساير مطالعات مبتنى بر الخوى برسيد هم تأييدشده 
در سلامت از ץ/Y ب/ به | 19/1 در گروه مداخله نشاندهنده تأثير آموزش بر اساس مدل يرسيد بر سلامت روان زنان ميانسال است.

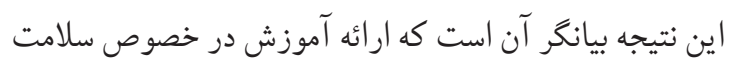

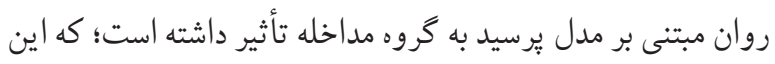

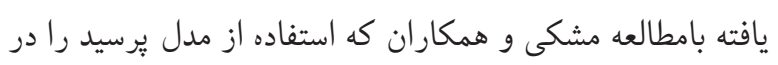

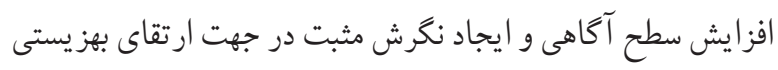

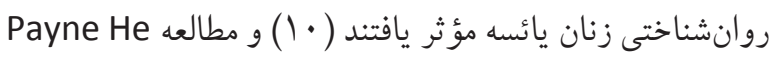
همكاران كه در خصوص تجزيهو تحليل محتواى برنامههاى مديريت

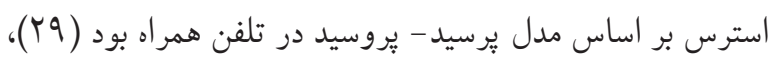
مطابقت داشت.

يُّوهشهاي انجامشده با استفاده از مدل يُرسيد، حاكى از اثربخشى

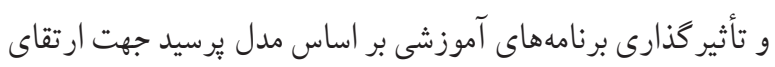

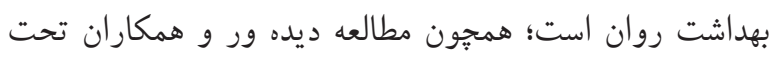
عنوان (أثير آموزش مديريت استرس از طريق مدل -PRECEDE

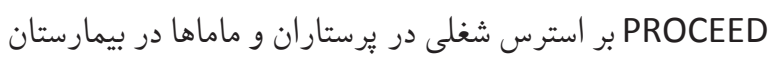

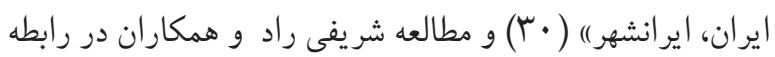

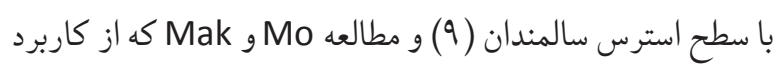

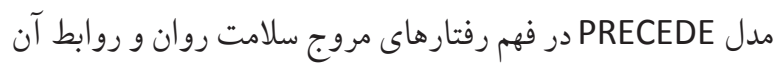

با رفاه و كيفيت زندكى حمايت مى كند (آ⿱艹).

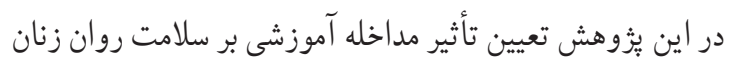

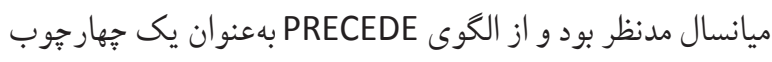

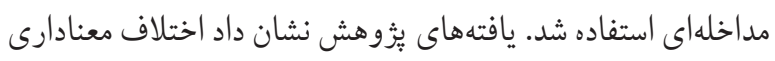

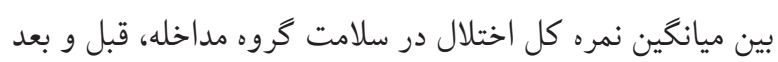

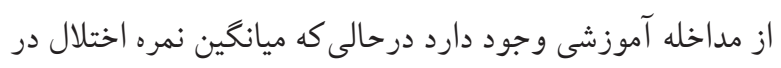

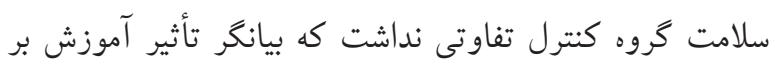

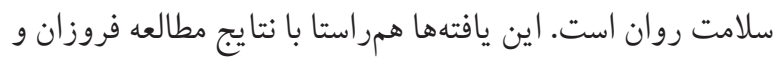

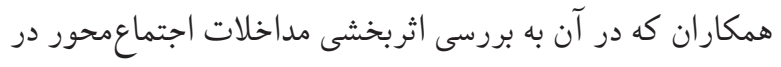

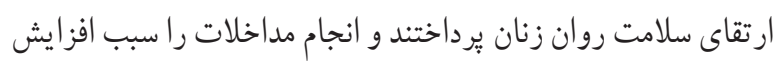
امتياز حيطه هاى مختلف كيفيت زندگى بهويزه حيطه روانى در گروه

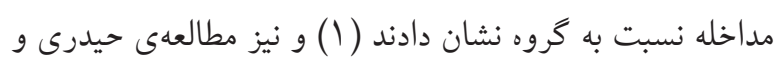

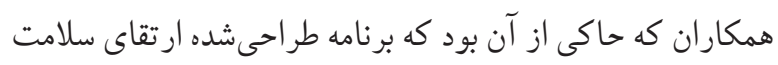

بر كيفيت زندگى (T) و حسينى و همكاران باهدف تأثير برنامه

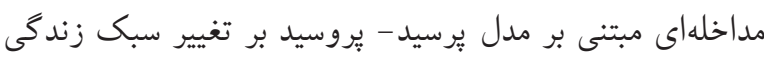

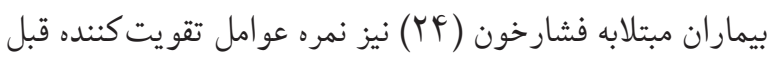
از آموزش يايين و بعد از مداخله آموزشى افزايش يافت كه در بهر راستاى يافتهاى بثزوهش حاضر است.

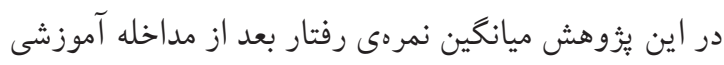
در گروه مداخله برخلاف گروه كنترل افزايش معنادارى يافته و موني اين نتيجه با يافته هاى مطالعهى ديده ور و همكاران با هدف تعيين تأثير آموزش مديريت استرس مبتنى بر مدل برسيد سالمندان (YO)

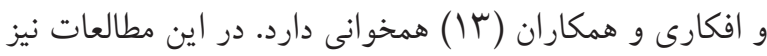
يس از آموزش، نمرهى رفتار افزايشيافته است. با توجه به اينكه

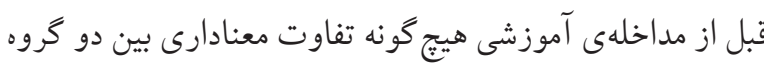
ازلحاظ اين تغيير مشاهده نشده بود، اين تغيير را مىتوان به مداخله

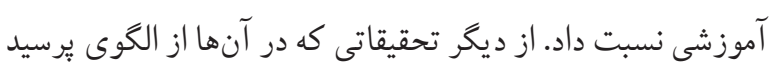

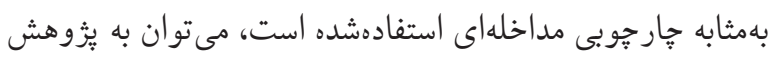
دهدارى درزمينه استفاده از الخوى برسيد براى ارتقاء كيفيت بيماران يس از جراحى قلب (Y)) ونيز مطالعه باز يور و همكاران با عنوان (تأثير يك برنامه آموزشى مبتنى بر مدل PRECEDE-PROCEED

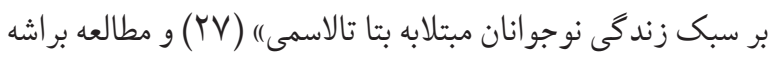

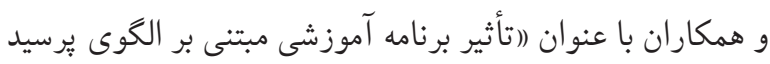

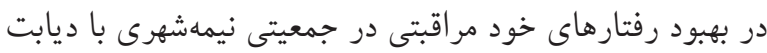

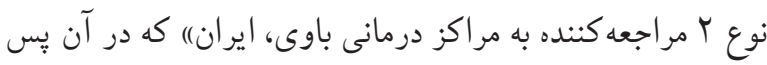

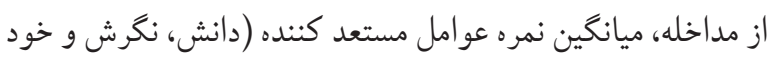

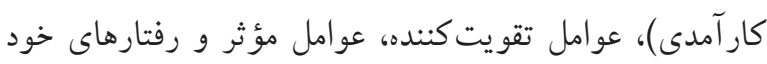

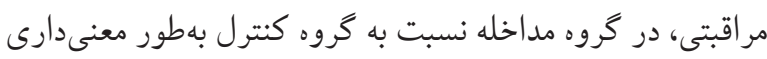
افزايش يافت (Y^) اشاره كرد. بر اساس نتايج ئزوهش حاضر، با توجه به اينكه قبل از مداخلهى آموزشى بين نمرهى سلامت روان در دو گروه مداخله و كنترل

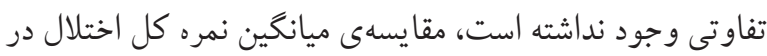

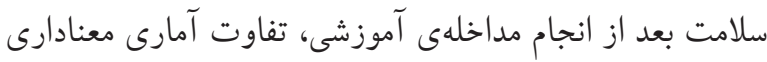
را در دو گروه مداخله و كنترل نشان داد. كاهش نمره كل اختلال 
بردن نمرهى سازههاى مستعد كننده (آكاهى و نگُش)، عوامل قادر كننده، عوامل تقويت كننده و رفتار، توانسته است بر سلامت روان زنان ميانسال مؤثر واقع شود. با توجه به عوارض جبران نايذير بيمارىهاى روحى و روانى و ايجاد هزينههاى بيمارستانى و درمانى به خانواده و دولت و با در نظر كرفتن اهميت موضوع و نتايج اين تحقيق كه مؤثر بودن آموزش جهت ارتقاء سلامت روان زنان ميانسال را نشان مى دهد مىتوان نتيجه گرفت براى ايجاد جامعهاى سالم و يويا بايد

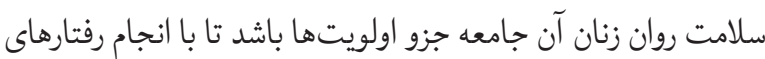
صحيح بهداشتى باعث تضمين سلامتى خود و نسل آينده و درنهايت موجب ارتقاى سلامت كل جامعه شوند. لذا توصيه مىشود از مدل يرسيد براى طراحى مداخلات آموزشى بهمنظور ارتقاى سلامت روان زنان ميانسال استفاده شود. تقدير و تشكر مئر

با تشكر از اساتيد محترم رشته آموزش بهداشت و ارتقاء سلامت كه هميشه از راهنمايىهاى ايشان استفاده كردهايم و سياس از تمامى زنان ميانسالى كه در اين مطالعه شركت داشتند.

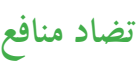
هيج گونه تضاد منافعى بين نويسندگان وجود ندارد.

\section{References}

1- Forouzan AS, Baradaran Eftekhari M, Mirabzadeh A, Malekafzali H, Dejman M, Sajadi H, Mohammadi F, Rafiee H, Rajabi M, Mottaghian L, Habibi E, Falahat K. Hakim Health Sys Res 2015; 18(1): 26- 33.

2- Tehrani H. Mental health stigma related to novel coronavirus disease (COVID-19) in older adults. Geriatrics \& gerontology international. 2020;20(8):796-7.. h tt p s: / / d o i . org / $10.1111 /$ g g i . 13985 PMid:32639082 PMCid:PMC7361788

3-Zahmatkesh Z, Peyman N, Tehrani H, Esmaily H. The Relationship between Postpartum Depression and Self-efficacy and Mental Health Literacy. Journal of Health Literacy. 2020;5(1):32-8. https://doi.org/10.22038/jhl.2020.46110.1097

4-Akbari M, Najafi S, Nadrian H. The Relationship between Social Capital Perceived Social Support and The Women's Mental Health in Sanandaj: a Community-Based Study. Iran J Health Educ Health Promot. 2017; 5 (3):155-163 https://doi.org/10.30699/acadpub.ijhehp.5.3.155

$$
\begin{aligned}
& \text { بر مدير يت استرس و رشد روحى مؤثر بوده است (^) و همجنين } \\
& \text { مطالعه Hawley و همكار انش (r (r) است. } \\
& \text { اين يزوهش محدوديتهايى داشت؛ اطلاعات جمع آورىشده } \\
& \text { از يرسشنامهها بهصورت خود اظهارى بودند كه ممكن است موجب } \\
& \text { شود افر اد بهخصوص رفتار را بيشازحد واقعى كزارش كنند و } \\
& \text { منعكس كننده عملكرد واقعى افر اد نباشد. همجنين در مرحله تكميل } \\
& \text { يرسشنامهى گس آزمون جون بايد توسط افر ادى تكميل مى شد كه در } \\
& \text { مرحله اوليه آن را تكميل كرده بودند در هنگام تكميل يرسشنامه در } \\
& \text { مرحله دوم در بعضى موارد خانمهاى ميانسال حضور نمى يافتند و } \\
& \text { لازم بود جِند بار يِيخيرى شود، كوتاه بودن فاصلهى زمانى ييكيرى } \\
& \text { نمونهاى يزوهش يس از آموزش از محدوديتهاى ديخر اين } \\
& \text { بلندمدت موردبررسى قرار دهد. } \\
& \text { نتيجاه كيرى }
\end{aligned}
$$

با استناد به نتايج بهدستآمده و با توجه به اينكه قبل از اجراى مداخلهى آموزشى تفاوت آمارى معنادارى بين دو گروه مداخله و كنترل ازنظر سازههاى مدل يرسيد و سلامت روان وجود نداشت. برنامهى آموزشى سلامت روان مبتنى بر مدل برسيد از طريق بالا

5- Ghanbari MR, Salari H, Taziki SA, Padash L, Yousefi MR, LotfaliNejad E. Survey of 15 Years and Older Women's Mental Health Status in Urban Population of Gorgan. Journal of Research Development in Nursing and Midwifery. 2013;10(1):77-83.

6-Fallahzadeh H,Ghafarikia M,Keyghobady N,Saadati H.Comparison of Depression and Anxiety in Employed Women With Housewives Women In Shiraz City in 2012. Journal of Toloo-e-Behdasht. 2014; 13 (1):115-123.

7- Mohammadi-Yeganeh L, Bastani F, Feizi Z, Agilar-Vafaie M, Haghani H. Effect of Stress Management Education on Mood and Perceived Stress among Oral Contraceptive Pill Users. IJN. 2008; 21 (53):63-73.

8- Heidari F, Mohammad khaN KERMANSHAHI S, vanaki Z, kazem nejad A. A Survey the effect of planned program of health promotion on stress management in middle-aged women. IJNR. 2011; 6 (22):17-23.

9-Sharifirad, G, Ghaffari, M, Zanjani, S, and Hassanzadeh, A. The effectiveness of educational intervention based on PRECEDE 
the level of stress (stress) seniors attending the eyes of the world centers of Tehran. Health Syst Res.2012 7(5).

10-Moshki M, Mohammadzadeh F, Yaghubi R, Pariafsai F. Application of Behavioral Analysis Phase of PRECEDE Model on Women's Psychological Well-being in the Menopausal Period. J Neyshabur Univ Med Sci. 2015; 3 (2):39-51.

11-Green LW, Kreuter MW. Health program planning: an educational and ecological approach. 4th Ed. New York: McGraw-Hill p.7-23; 2005.

12-Zendehtalab HR, The effect of an educational program designed based on PRECEDE- PROCEED Model on adolescents'mental health and their parents' participation. Evidence Based care 2012; 2(1):45-54.

13- Bridges LS, Sharma M, Lee JHS, Bennett R, Buxbaum SG, Reese-Smith J. Using the PRECEDE-PROCEED model for an online peer-to-peer suicide prevention and awareness for depression (SPAD) intervention among African American college students: experimental study. Health Promot Perspect. 2018; 8(1):15-24. https://doi.org/10.15171/hpp.2018.02 PMid:29423358 PMCid:PMC5797304

14-Afkari M E, Solhi M, Matin H, Hoseini F, Mansoorian M. The Efficiency of Educational Intervention Based on PRECEDE Educational Method in the Promotion of Life Quality of the Aged Under the Coverage of Tehran Cultural House of Aged People 2009. Sija. 2011; 5 (4)

15- Hlaing PH, Sullivan PE, Chaiyawat P. Application of PRECEDE-PROCEED Planning Model in Transforming the Clinical Decision Making Behavior of Physical Therapists in Myanmar. Frontiers in public health. 2019;7:114. https://doi.org/10.3389/fpubh.2019.00114 PMid:31134176 PMCid:PMC6517479

16-Moshki M, Ghofrani Pour F, Azad Fallah P, Haji Zadeh E. Implementation of participatory-educational program based on Precede model for self-esteem and psychological well-being enhancement of university students. HormozganMedical Journal 2010; 14(1):22-31.

17-Lesan SH, Ghofrani Pour F, Byrshk B, Faghihzadeh S. Application of PRECEDE in reducing Tehranian firemen anxiety. Iraninan Psychiatry and Clinical Psychology 2003; 9(2): 77-84.

18-Hazavehei SM, Sabzmakan L, Hassan Zadeh A, Rabie K. The effect of PRECEDE Model-based educational program on depression level in patients with coronary artery bypass grafting. The Journal of Qazvin University of Medical Sciences \& Health Services 2008; 12(2): 32-40.

19-Yates P, Edwards H, Nash R, Aranda S, Purdie D, Najman J, et al. A randomized controlled trial of a nurseadministered educational intervention for improving cancer pain management in ambulatory settings. Patient Educ Couns 2004; 53(2): 227-37.
https://doi.org/10.1016/S0738-3991(03)00165-4

20-Fathizadeh S, Shojaeizadeh D, Mahmoodi M, Garmarodi G, Amirsardari M, Azadbakht $\mathrm{M}$ et al. The Impact of Health Education Based on PRECEDE Model on Knowledge, Attitude and Behavior of Grade Nine Female Students about Iron Deficiency Anemia in Qazvin. J.health. 2016; 7 (3):321-330.

21- Afkari ME, Taghdisi MH. The Effect of an educational intervention based on the PRECEDE model on quality of life improvement in the elderly afiliated with Tehran culture house for the aged-2009. Iranian Journal of Health Education and Health Promotion. 2013;1(1):21-33.

22-Dadipoor S, sayahi Y, Alavi A, Naghavi K, Safari Moradabadi A. Using Precede model to investigate the correlates of menopausal women's life quality in Bandar Abbas... Avicenna J Nurs Midwifery care. 2015; 23 (1):84-93.

23- Doshmangir P, Shirzadi S, Tagdisi MH, Doshmangir L. Effect of an Educational Intervention According to the PRECEDE Model to Promote Elderly Quality of Life. Journal of Education and Community Health. 2014;1(2):1-9. https://doi.org/10.20286/jech-01021

24-Hosseini SG, Shojaeizadeh D, Sanagu A, Vakili MA, Mirkarimi $\mathrm{K}$, Jahanshahi R. Effect of educational intervention on self-care behaviors among patients with diabetes: An application of PRECEDE model. Ann Trop Med Public Health 2017; 10:707-14.

25-Didehvar M, Jalili Z, Zareban I, Bakhshani N M, Shahrakipour M. The Effect of Stress Management Education Based on PRECEDE Model on Occupational Stress of Nurses in Hospitals of Iranshahr, Iran. Strides Dev Med Educ. 2015; 12 (3):472-484.

26- Dehdari T, Heidarnia A, Ramezankhani A, Sadeghian S, Ghofranipour F, Etemad S. Planning and evaluation of an educational intervention programme to improve life quality in patients after coronary artery bypass graftsurgery according to PRECEDE-PROCEED model. J Birjand Univ Med Sci. 2008; 15 (4):27-37.

27-Bazpour M, Gheibizadeh M, Saki Malehi A, Keikhaei B. The Effect of a Training Program Based on the PRECEDEPROCEED Model on Lifestyle of Adolescents with BetaThalassemia: A Randomized Controlled Clinical Trial. Int J Hematol Oncol Stem Cell Res. 13(1):12-19.

28-Barasheh N, Shakerinejad G, Nouhjah S, Haghighizadeh $\mathrm{MH}$. The effect of educational program based on the precede-proceed model on improving self-care behaviors in a semi-urban population with type 2 diabetes referred to health centers of Bavi, Iran. Diabetes Metab Syndr. 2017; 11(suppl 2):S759-S76531- Phoenix K. H. Mo, Winnie W. S. Mak.The importance of mental health. Health Education \& Behavior. 200835 (4): 574-587. https://doi.org/10.1016/j.dsx.2017.05.012 PMid:28669595 
29- Payne HE, Wilkinson J, West JH, Bernhardt JM. A content analysis of precede-proceed constructs in stress management mobile apps. mHealth. 2016;2(2).

30- Didehvar M, Zareban I, Jalili Z, Bakhshani N-M, Shahrakipoor $M$, Balouchi A. The effect of stress management training through PRECEDE-PROCEED model on occupational stress amongnursesandmidwivesatIranhospital,Iranshahr.Journal of clinical and diagnostic research: JCDR. 2016;10(10):LC01. https://doi.org/10.7860/JCDR/2016/22569.8674 PMid:27891358 PMCid:PMC5121696
31- Phoenix K. H. Mo, Winnie W. S. Mak.The importance of mental health. Health Education \& Behavior. 200835 (4): 574-587.

32- Hawley G, Horwath C, Gray A, et al. Sustainability of health and lifestyle improvements following a non-dieting randomised trial in overweight women. Preventive Medicine; 200847:593-599. https://doi.org/10.1016/j.ypmed.2008.08.008 PMid:18817809 